\title{
Advances in Stem Cell Therapy for Erectile Dysfunction
}

\author{
Ching-Shwun Lin \\ Knuppe Molecular Urology Laboratory, Department of Urology, School of Medicine, University of California, \\ San Francisco, CA 94143-0738, USA \\ Correspondence should be addressed to Ching-Shwun Lin; clin@urology.ucsf.edu
}

Received 21 November 2013; Accepted 20 January 2014; Published 12 March 2014

Academic Editor: Enzo Vicari

Copyright (c) 2014 Ching-Shwun Lin. This is an open access article distributed under the Creative Commons Attribution License, which permits unrestricted use, distribution, and reproduction in any medium, provided the original work is properly cited.

\begin{abstract}
Stem cell (SC) therapy for erectile dysfunction (ED) has been investigated in 35 published studies, with one being a small-scale clinical trial. Out of these 35 studies, 19 are concerned with cavernous nerve $(\mathrm{CN})$ injury-associated ED while 10 with diabetes mellitus- (DM-) associated ED. Adipose-derived SCs (ADSCs) were employed in 18 studies while bone marrow SCs (BMSCs) in 9. Transplantation of SCs was done mostly by intracavernous (IC) injection, as seen in 25 studies. Allogeneic and xenogeneic transplantations have increasingly been performed but their immune-incompatibility issues were rarely discussed. More recent studies also tend to use combinatory therapies by modifying or supplementing SCs with angiogenic or neurotrophic genes or proteins. All studies reported better erectile function with SC transplantation, and the majority also reported improved muscle, endothelium, and/or nerve in the erectile tissue. However, differentiation or engraftment of transplanted SCs has rarely been observed; thus, paracrine action is generally believed to be responsible for SC's therapeutic effects. But still, few studies actually investigated and none proved paracrine action as a therapeutic mechanism. Thus, based exclusively on functional outcome data shown in preclinical studies, two clinical trials are currently recruiting patients for treatment with IC injection of ADSC and BMSC, respectively.
\end{abstract}

\section{Introduction}

Erectile dysfunction (ED) is a term recommended by a panel of experts in 1992 to replace the term "impotence" [1]. These experts also defined ED as an inability of the male to attain and/or maintain penile erection sufficient for satisfactory sexual performance. Although not life threatening by itself, $\mathrm{ED}$ is a strong predictor of high-mortality diseases such as coronary artery disease and cardiovascular disease [25]. ED does directly and negatively impact the quality of life of the afflicted men and their spouse [6-11]. In a 1999 report the worldwide prevalence of ED was estimated to be 152 million men in 1995 and predicted to increase to 322 million men by 2025 [12]. While the majority of ED cases can be treated with currently available medications or devices, approximately $20 \%$ of the overall ED patient population remains unresponsive to treatment [13], and in certain patient populations, such as those having diabetes mellitus (DM) or having undergone radical prostatectomy (RP), the failure rates are even higher, at 40\% [14-16]. Moreover, regardless of their therapeutic efficacy or inefficacy, all current treatment options treat only the symptoms, not the underlying causes, and most of them need to be taken by or administered to the patient when having an erection which is perceived as necessary. Thus, current research efforts are geared toward finding long-term solutions that can reverse the pathogenesis of ED and thereby restore the patient's ability to achieve natural penile erection. One of such research efforts is the investigation of stem cells (SCs) as therapeutic agents, and in this review article I will summarize and discuss all available relevant data in this field of research.

\section{Erectile Function}

Penile erection is a physiological process that involves the expansion and elongation of a paired cylindrical structure called corpora cavernosa (singular: corpus cavernosum, CC) that run the length of the penis [17]. Inside each CC is a maze of miniscule chambers called sinusoids that are collapsed and occupy a minimal amount of space when the penis is in the flaccid state. When a man is sexually aroused, blood enters 
the sinusoids, resulting in their expansion and thus penile erection. When sexual stimulation subsides, blood exits the sinusoids, and the penis returns to the flaccid state.

The cycle of sinusoidal expansion and collapse is locally controlled by smooth muscle cells (SMCs, or CSMCs as pertaining to CC), which form a multilayered structure as part of the sinusoidal wall $[18,19]$. When CSMCs are in a contracted state, blood flow into the sinusoids is kept at a minimum; when CSMCs transit to a relaxed state, blood flow into the sinusoids is increased, resulting in sinusoidal expansion. The cycle of CSMC contraction and relaxation is in turn controlled by two other tissue components inside the CC, namely, the cavernous endothelial cells (CECs) and the cavernous nerves (CNs). CECs are located as a single layer of cells alongside the CSMCs inside each sinusoid, and together, CECs and CSMCs form the wall that defines each sinusoid $[18,19]$. CNs, which arise from neurons in the inferior hypogastric plexuses in humans or in the major pelvic ganglia (MPG) in the rat [20,21], track throughout the CC and end in the vicinity of CSMCs $[18,19]$. Sexual stimulation causes CNs to release nitric oxide (NO), which enters nearby CSMCs, triggering their relaxation [22-24]. The subsequent increase of blood flow into the sinusoids induces shear stress on the CECs, triggering their release of NO. This CEC-derived NO is believed to permit a sustained CSMC relaxation that is essential for a satisfactory intercourse [25-29].

The paired CC is enveloped in a dense fibrous sheath called tunica albuginea (TA). During erection, the increased blood flow into the sinusoids causes CC to expand and compress against the TA. Being a sturdy and resilient structure, the TA permits CC expansion, but with increasing resistance. As the tension between the expanding $\mathrm{CC}$ and the resisting TA increases, so does the overall penile rigidity. Furthermore, the compression of CC against TA causes the closure of subtunical veins that otherwise would allow the escape of blood from the sinusoids. Such a venous occlusive mechanism ensures that the CC remains fully engorged and the penis fully erect until the cessation of sexual stimulation [17].

$\mathrm{NO}$, which is critical for triggering CSMC relaxation, is formed within CECs and CNs by nitric oxide synthase (NOS) that catalyzes the conversion of $\mathrm{L}$-arginine and oxygen to Lcitrulline and $\mathrm{NO}$ [30]. While performing the same function in NO production, the endothelial NOS (eNOS) and the neuronal NOS (nNOS) are encoded by two separate genes [30]. More importantly, from a technical standpoint, eNOS and nNOS are sufficiently different in their protein sequences so as to permit the generation of their specific antibodies $[31,32]$. In ED research, including many studies that will be discussed in this review, these antibodies have proven to be highly valuable for the assessment of ED-related changes in the cavernous endothelium and nerves.

NO enters CSMCs by diffusion, and once inside, it activates the soluble guanylyl cyclase, which then catalyzes the conversion of GTP to cGMP $[22,23]$. When cGMP concentration is sufficiently high, activation of cGMP-dependent kinase (also known as protein kinase G, PKG) occurs, and this leads to the phosphorylation of several downstream targets (e.g., ion channels), causing CSMCs to relax and thus penile erection [22, 23]. When sexual stimulation ceases, cGMP production is also halted. Meanwhile, existing cGMP is hydrolyzed by phosphodiesterases (PDEs), most notably, PDE5 $[33,34]$. When cGMP concentration drops below a threshold level, PKG is deactivated and its downstream targets dephosphorylated, thereby returning CSMCs to the contracted state and the penis to the flaccid state $[22,23]$.

\section{Erectile Dysfunction}

The worldwide prevalence of ED was estimated to be 152 million in 1995 and predicted to be 322 million by 2025 [12]. ED can be classified as psychogenic, organic, or mixed psychogenic/organic [17]. The organic type of ED is further classified into neurogenic, vasculogenic, cavernous, hormonal, drug-induced, and systemic disease-related [17]. For all published SC-for-ED studies, only the neurogenic, vasculogenic, and cavernous types are relevant. Specifically, in concern with neurogenic and vasculogenic types, the relevant studies focused on $\mathrm{CN}$ injury-associated and DMassociated ED, respectively. And, in concern with cavernous type of $\mathrm{ED}$, which loosely defines local tissue abnormalities, there have been two TA injury-related SC-for-ED studies.

The majority of organic types of $\mathrm{ED}$ can be treated with intracavernous (IC) injection of erectogenic agents, transurethral prostaglandin suppository, vacuum device, and/or PDE5 inhibitors (PDE5Is) [35]. In particular, PDE5Is are currently the most prescribed treatment because of their ease of use (as orally taken pills) and overall proven efficacy [35]. However, in a recent study of 327 ED patients who were prescribed PDE5Is by their physicians, only 148 (45.3\%) were still using the medication during a 3-year follow-up period, while 160 (48.9\%) had discontinued and 19 (5.8\%) never took the medication [36]. Thus, among those who had taken PDE5Is, more than half $(52 \% ; 160 / 308)$ had decided not to continue. When asked to choose among 11 reasons for discontinuation, $38 \%$ of the dropout patients selected "noneffectiveness." Other significant reasons chosen were "concerns about the cardiovascular safety of PDE5Is" (15.7\%), cost (13.7\%), and "lack of spontaneity" (8.7\%). When categorized by specific ED types, patients who were diabetic had the highest discontinuation rate $(28 / 36 ; 78 \%)$, followed by patients whose ED was caused by treatments such as RP (37/56; 66\%) [36]. Such high dropout rates for these two types of ED are not entirely unexpected, as an earlier study already identified them as least responsive to PDE5I treatment [14]. These two types of ED therefore will be discussed in detail in the following two sections. For other types of ED that have been investigated as SC treatment targets, only the TA injuryassociated ED will also be discussed in detail in a separate section. The reasons are as follows: (1) it is necessary to clarify whether TA injury can truly cause ED, (2) hyperlipidemiaassociated ED has been investigated in only one SC-for-ED study, (3) aging-associated ED is related to the normal process of aging, not to any specific disease, and (4) these latter two types of ED are usually responsive to PDE5I treatment. 


\section{Diabetes-Associated ED}

In an official document titled "National Diabetes Statistics, 2011," the National Institute of Health of the USA reports that DM affects 25.8 million people, or $8.3 \%$ of the general population in the USA, and among residents 65 years of age and older, 10.9 million (26.9\%) had DM in 2010 [37]. In a peerreviewed publication that analyzed prior epidemiological studies totaling 370 country-years and 2.7 million participants, Danaei et al. [38] reported that the number of people with DM worldwide increased from 153 million in 1980 to 347 million in 2008. Furthermore, in a forward-looking projection, the International Diabetes Federation estimated that by 2030 the number of people with DM worldwide will be 552 million [39]. Thus, the global diabetes epidemic is alarmingly real.

$\mathrm{DM}$ is associated with a large assortment of complications, including ED. For men with DM, 50-75\% have ED, regardless of age [40]. Diabetic men also tend to incur ED 10-15 years earlier and are 3 times more likely to have ED than nondiabetic men $[41,42]$. Importantly, both the severity of ED and the impact on quality of life by ED are significantly greater in diabetic than in nondiabetic men $[43,44]$. DM-associated ED is also highly refractory to PDEI treatment, with only $44 \%$ success rate, compared to $85 \%$ for hypogonadal ED patients [14]. Diabetic ED patients also ranked the highest in terms of discontinuation of treatment with PDE5Is (at a dropout rate of $28 / 36$ or $78 \%$ ) [36]. Thus, the identification of an effective treatment for DM-associated $\mathrm{ED}$ is one of the most important objectives of current ED research efforts.

$\mathrm{DM}$ is a systematic disease that affects every part of the body. In the penis, it is associated with reduced contents of all three key components for erectile function, namely, $\mathrm{CN}$, CEC, and CSMC [45-49]. The reduction of CEC content is likely due to DM-induced apoptosis in CEC as demonstrated by immunohistochemical analysis of CC samples between diabetic and nondiabetic patients [50]. This clinical histological finding has recently been corroborated by a basic science study, which identified mitochondrial fragmentation and cellular apoptosis in CECs cultured in high glucose medium $[32,51]$. Histological analysis of CC samples also identified a significantly higher apoptotic index in the CSMC of diabetic versus nondiabetic rats [52]. Similarly, the reduced penile $\mathrm{CN}$ content has been shown to be due to apoptotic cell death of nNOS-positive neurons in the MPG of diabetic rats [48]. Thus, how to prevent and/or reverse these pathological processes is critically important for the effective treatment of DM-associated ED. In this regard, SC therapy has been considered promising, due to SC's well-known regenerative capacity.

\section{Postprostatectomy and Postradiotherapy ED}

Prostate cancer is the most common malignancy in men, with estimated numbers of new cases and related deaths being 217,730 and 32,050, respectively, in the USA in 2010 [53]. As prostate cancer is usually locally confined ( $~ 80 \%$ of cases), the most common treatments have been RP or external beam radiation therapy (RT) [54]. However, despite being highly effective, these treatments often incur after treatment complications, such as ED $[55,56]$. In a recent study of 1655 men treated with RP or RT, the reported incidence of ED ranges from $60.8 \%$ to $93.9 \%$, depending on treatment choice and assessment time (2, 5, or 15 years after treatment) [57].

It is generally agreed that post-RP ED is caused by inadvertent injury to the $\mathrm{CNs}$, which run alongside the prostate. However, despite the introduction of nerve-sparing RP 30 years ago, ED remains a frequent consequence of such surgeries [58, 59]. Therefore, it is now commonly believed that, although leaving the CNs intact, nerve-sparing RP still causes subtle changes that are not obvious to the surgeons [55, 60]. These changes cause CNs to undergo Wallerian degeneration and eventually lose their connection to the corpora cavernosa [56, 61]. Alternatively, the surgery-incurred insults may temporarily prevent the $\mathrm{CNs}$ from releasing $\mathrm{NO}$ into the $\mathrm{CC}$, and without $\mathrm{NO}$-induced engorgement, the penile tissue becomes hypoxic and its CSMC replaced by collagens $[56,60,61]$. In support of this theory, a reduced smooth muscle to collagen ratio has been observed in the penis of $\mathrm{CN}$ injury animal models [62-66] and in CC biopsies of RPtreated patients [67].

$\mathrm{RP}$ and $\mathrm{RT}$ are used to treat prostate cancer at comparable rates [54]; they are also associated with posttreatment ED at similar rates [57]. However, while RP-associated ED has been intensively investigated at the basic science level, RTassociated ED is rarely studied [49]. Nevertheless, three independent studies have found that radiation over the lower abdomen in the rat caused reductions in erectile response and in CN and CSMC contents [49, 68, 69]. Thus, post$\mathrm{RP}$ and post-RT ED appear to share a common pathological mechanism, that is, treatment-induced $\mathrm{CN}$ injury followed by CSMC atrophy.

Similar to other types of ED, post-RP and post-RT ED are most commonly treated with PDE5Is [56]. However, as its name indicates, a PDE5I inhibits PDE5, which, by breaking down cGMP, terminates the NO-activated erectile signaling pathway $[23,33]$. Therefore, when $\mathrm{CNs}$ are injured, as in the situation with RP or RT-treated patients, their ability to release NO into CC is compromised, and if there is no NO release into CC, erection would not occur, regardless whether PDE5 is inhibited or not. This dependence on a functional $\mathrm{CN}$ may explain why PDE5Is have a low success rate $(\sim$ $43 \%)$ in treating post-RP ED [14] and a high discontinuation rate $(\sim 66 \%)$ in post-RP ED patients who were nevertheless prescribed with PDE5Is [36]. Thus, it is obvious that the effective treatment of post-RP and post-RT ED requires repair of the damaged $\mathrm{CN}$, and this has been the goal of the majority of SC-for-ED studies, especially those published in the past two years.

\section{Peyronie's Disease-Associated ED}

The estimated prevalence of PD varies greatly among different studies, with the highest being up to $7.1 \%$ of men in the general population [70]. PD is characterized by the presence of a fibrous plaque (or plaques) in the TA that causes pain 
and deformity (curvature, narrowing, and shortening) in the erect penis [70]. PD therefore negatively impacts the patient's sexual function and partner relationship [71]. However, in popular media, such as the Internet, PD patients' sexual dysfunction is often incorrectly defined as a type of "erectile dysfunction," despite the fact that most PD patients are able to achieve erection. Nevertheless, in serious scientific publications, $\mathrm{PD}$ is frequently described in the Introduction section as a disease that directly causes ED, with reference to a study by Lopez and Jarow [72]. In that study, 76 out of 95 (80\%) PD patients were determined as having concomitant $\mathrm{ED}$, and $36 \%$ and $59 \%$ of these $\mathrm{PD}+\mathrm{ED}$ patients were further identified as having abnormal arterial blood flow and venoocclusive dysfunction, respectively. Thus, the authors concluded that, when compared to abnormal arterial blood flow, veno-occlusive dysfunction was the principal cause of $\mathrm{ED}$ in PD patients. However, it should be noted that the study never examined whether PD (TA plaque) caused veno-occlusive dysfunction or ED. In another study that evaluated $143 \mathrm{PD}$ patients, only 27 (19\%) were found to have concomitant ED, and 22 (including 4 diabetics) of the $27 \mathrm{PD}+\mathrm{ED}$ patients were found to have veno-occlusive dysfunction [73]. So, on one hand, these two studies disagree sharply in the prevalence of ED among PD patients (80\% versus 19\%), but on the other, they do agree that veno-occlusive dysfunction is the principal cause of ED in PD patients. Importantly though, neither study provides evidence that PD (TA plaque) caused veno-occlusive dysfunction or ED. In fact, in an earlier study only 18 out of 62 PD patients (29\%) were found to have concomitant ED, and 17 out of these $18 \mathrm{PD}+\mathrm{ED}$ patients were further identified as having some underlying diseases (such as DM) that contributed to their ED [74]. Therefore, none of these three studies provides evidence that PD (TA plaque) is a direct cause of ED in PD patients. Finally, in the only animal study that attempted to answer why PD patients suffer from ED, PD was simulated in the rat by injection of transforming growth factor- $\beta$ (TGF- $\beta$ ) into the TA (to induce fibrosis) or by surgical incision in the TA (to cause trauma) [75]. Six weeks later both groups of rats were found to have altered TA histology and lowered erectile response when compared to sham-treated rats. Therefore, this study appears to have obtained evidence that TA abnormalities can cause ED, but the question remains whether treatment of $\mathrm{PD}$ can result in the restoration of erectile function.

Plaque excision followed by patch grafting is a common surgical procedure for the correction of penile deformities in PD patients [76]. However, in spite of its proven efficacy, postsurgical complications such as ED can occur [77]. Therefore, various approaches, including the use of novel graft materials, have been investigated toward minimizing the occurrence of these complications [76]. In a recent animal study, porcine small intestine submucosa (SIS), which has already been used for TA reconstruction in PD patients, was seeded with adipose-derived stem cells (ADSCs) and then grafted into incised rat TA to see if ADSC seeding can reduce the incidence of postsurgery ED [78]. In another recent animal study [79] ADSC was injected into the TA of TGF$\beta$-induced PD rats to see if ADSC can reduce the severity of
TABLE 1: Number of published stem cells for erectile dysfunction studies.

\begin{tabular}{lccc}
\hline Years & 2004-2011 & 2012-2013 & 2004-2013 \\
\hline Total & Number of studies & \\
Disease model & $\mathbf{1 5}$ & $\mathbf{2 0}$ & $\mathbf{3 5}$ \\
$\quad$ Aging & 2 & 1 & \\
CN injury & 7 & 12 & 3 \\
Hyperlipidemia & 1 & 0 & 19 \\
T1DM & 2 & 6 & 1 \\
T2DM & 2 & 0 & 8 \\
TA injury & 0 & 2 & 2 \\
SC type & & & 2 \\
ADSC & 5 & $13^{\mathrm{a}}$ & \\
BMMNC & 1 & 0 & 18 \\
BMSC & 4 & 5 & 1 \\
EPC & 1 & 0 & 9 \\
ESC & 1 & 0 & 1 \\
SkMSC & 2 & 1 & 1 \\
Testis SC & 0 & 1 & 3 \\
UCBSC & 1 & 0 & 1 \\
\hline
\end{tabular}

${ }^{a}$ Including 2 studies using SVF cells.

${ }^{\mathrm{b}}$ Probably BMMNC.

ED. Further discussion on these two studies will be given in "Animal Models" subsection.

\section{Current State of Stem Cell Therapy for Erectile Dysfunction}

The first SC-for-ED study was published in 2004, and since then, up to November 2013, there have been a total of 34 additional studies in this field of research (Table 1). While 15 of these studies were published between 2004 and 2011, 20 were published after 2011. Thus, it is evident that an accelerated pace of publication occurred at the start of 2012 . In any event, among all 35 studies, 19 chose CN injuryassociated ED as the disease target, and 18 employed ADSC as the therapeutic cell type (Table 1). While the disease target preference reflects clinical needs (i.e., post-RP and post-RT $\mathrm{ED}$ as described earlier), the cell type choice is most likely due to ADSC's abundant tissue source, ease of isolation, and proven therapeutic efficacy across all medical disciplines (see details under "adipose-derived stem cell").

As clinical trial of SC therapy for ED is not yet approved in most countries, there has been only one published clinical SC-for-ED study and it involved only 7 type 2 DM (T2DM) patients [80]. While that study was carried out in Korea, two clinical trials have been approved in France and the USA and are currently recruiting patients. The French trial (Identifier: NCT01089387) is a phase I-II trial and will test the safety and benefit of IC injection of autologous bone marrow mononucleated cells (BMMNC) in post-RP ED patients. The US trial (Identifier: NCT01601353) will evaluate the safety 
and treatment efficacy of IC injection of autologous ADSC in patients with organic ED.

In addition to the above-mentioned research and clinical trials, SC's therapeutic potential has also inspired several business opportunities. By searching the Internet with "stem cell erectile," one can find many "treatment centers" that offer autologous ADSC treatment for ED at prices of several thousand US dollars. While most of these businesses are located in developing countries such as the Philippines and Thailand, some indicate their presence in the USA. This is surprising because for-profit SC treatment of any disease is illegal in the USA, and criminal convictions have been handed down on cases that involved treating patients with SCs. Therefore, at issue are probable fraudulent advertisements. In any event, SC therapy for ED remains largely in the preclinical investigational stage, and this is what will be discussed in the following sections.

\section{Animal Models}

All but one preclinical SC-for-ED studies used rats as animal models; the singular exception used mice (Tables 2, 3, and 4). Aging animal models were used in 3 studies (Table 2), and they were rats between 20 and 30 months of age. Hyperlipidemia rat model was used in one study (Table 2), and it was established by feeding with a commercially formulated highfat diet (mainly 2\% cholesterol and 10\% lard) for 5 months. The high cost of this diet and the lengthy time requirement are hindering factors for this model's widespread usage. TA injury animal models were used in two studies (Table 2), and they were established by two different procedures. In the earlier study, a $0.5 \mathrm{~cm}$ incision was made through both lateral sides of the rat's TA, and a SIS graft seeded or not seeded with ADSCs was then interpositioned into the incision and sutured. As such, this animal model should probably be called a TA reconstruction rather than a TA injury ED model. In the later study, TA injury was induced by injection of $50 \mu \mathrm{g}$ of TGF- $\beta$ into the TA, and one day later, ADSC was injected into the same site as a treatment for the injured TA. Thus, as far as treatment target is concerned, this is an acute TA injury, not PD, animal model, because PD is characterized clinically as a chronic disease.

Type 1 DM (T1DM) animal models were used in 8 studies (Table 3), and they were all established by intraperitoneal injection of streptozotocin (STZ). The ease of this DMinduction procedure is certainly the main reason why this animal model is frequently used in research despite the fact that only $5 \%$ of DM patients are type 1 . On the other hand, only one study has used T2DM animal model-the Zucker Diabetic Fatty (ZDF) rat. The high cost ( $>300$ per rat) of this mutant rat is probably prohibitory for most researchers to consider its usage, especially when knowing that STZinduced DM animal models are well accepted as clinically relevant.

CN injury models were used in 19 SC-for-ED studies (Table 4), and their purposes were to simulate postradical prostatectomy (post-RP) or postradiation therapy (post-RT) ED. To simulate post-RP ED, the investigator performs a lower abdominal incision and, with the aid of a dissecting microscope, identifies the two branches of $\mathrm{CN}$, which arise from the MPG and course proximally on both sides of the prostate and distally alongside the urethra toward the penis. An injury is then applied at a location 2-5 mm from the MPG. The types of injury can be crush, freezing, transection, or resection. Crush is commonly done by applying a hemostatic clamp to the $\mathrm{CN}$ so as to simulate accidental nerve contusion or traction that occurs during nerve-sparing RP. Freezing is commonly done by applying a cryoprobe to the $\mathrm{CN}$ so as to offer another way of preserving nerve structural continuity. Both transection (a simple cut) and resection (removal of a $\mathrm{CN}$ segment) can be considered as representing nonnerve sparing RP, but transection is more likely to allow nerve reconnection than resection is. Thus, among all types of experimental $\mathrm{CN}$ injuries, resection is the most severe. In the majority of SC for CN injury ED studies, crush is most frequently used (11/19, Table 4).

While hundreds of studies have employed post-RP ED animal models, only 5 studies have worked with post-RT ED models $[68,69,105,113,114]$. These studies used similar procedures but with slightly different dosage, duration, and frequency of radiation. In the study by van der Wielen et al. [114], a $3 \mathrm{~mm}$ thick lead shield with a $3 \mathrm{~cm} \times 4 \mathrm{~cm}$ window was placed on the rat to confine the radiation to the lower abdomen. Radiation was then delivered at 7.4 Gy for 5 consecutive days. This protocol was initially adopted in our recently published study [105], but after getting a $50 \%$ death rate, we modified it by using a lead shied with a smaller window $(2.5 \mathrm{~cm} \times 3 \mathrm{~cm})$ and delivering radiation at a smaller dosage ( $4 \mathrm{~Gy} /$ day for 5 days). These modifications resulted in no death, yet achieving the goal of inducing ED in the irradiated rats. Thus, some adjustments appear to be necessary for each research group to produce the optimal post-RT ED animal model.

\section{Stem Cell Basics}

SCs can be classified according to their differentiation potential into pluripotent and multipotent, where pluripotent signifies the potential to differentiate into all cell types, whereas multipotent, some but not all cell types. SCs can also be classified according to their source into embryonic (ESC) and adult (ASC), where embryonic indicates the inner cell mass of a blastocyst, whereas adult, various tissues of a developed or developing individual. In terms of differentiation potential, ESC is pluripotent whereas ASC multipotent. However, many studies, including several in ED field, have stated that SCs isolated from adult tissues are pluripotent. This misunderstanding is a result of accepting in vitro differentiation data that were generated by using nonphysiological conditions and nonspecific cell markers (see below for further details). Furthermore, even if in vitro evidence is acceptable, there is no possibility to demonstrate ASC's differentiation into "all" cell types. As such, it is prudent to define ASCs as multipotent. In any event, depending on their tissue origin or the tissue type they can differentiate into, ASCs can be further classified into hematopoietic, neural, epithelial, and 
TABLE 2: Published studies of stem cell therapy for noncavernous nerve injury, nondiabetic erectile dysfunction.

\begin{tabular}{|c|c|c|c|c|c|c|}
\hline $\begin{array}{l}\text { Publication } \\
\text { year }\end{array}$ & First author & Animal model & Stem cell type & Modification/supplementation* & Transplantation route & Reference \\
\hline 2007 & Bivalacqua & Aging rat & Allogeneic BMSC & eNOS transduction & IC & {$[81]$} \\
\hline 2008 & Nolazco & Aging rat & Mouse SkMSC & None & IC & {$[82]$} \\
\hline 2010 & Abdel Aziz & Aging rat & Allogeneic BMSC & None & IC & [83] \\
\hline 2010 & Huang & Hyperlipidemia rat & Autologous ADSC & None & IC & {$[84]$} \\
\hline 2012 & $\mathrm{Ma}$ & TA injury rat & Autologous ADSC & None & SIS graft & [78] \\
\hline 2013 & Castiglione & TA injury rat & Human ADSC & None & Intratunical & [79] \\
\hline
\end{tabular}

${ }^{*}$ For enhancing stem cell's therapeutic efficacy.

TABLE 3: Published studies of stem cell therapy for diabetic erectile dysfunction.

\begin{tabular}{|c|c|c|c|c|c|c|}
\hline $\begin{array}{l}\text { Publication } \\
\text { year }\end{array}$ & First author & $\begin{array}{c}\text { Patients/animal } \\
\text { model }\end{array}$ & Stem cell type & Modification/supplementation* & Transplantation route & Reference \\
\hline 2010 & Bahk & T2DM patients & Allogeneic UCBSC & None & IC & {$[80]$} \\
\hline 2010 & Garcia & ZDF rat & Autologous ADSC & None & IC & [85] \\
\hline 2011 & Gou & STZ rat & Allogeneic EPC & VEGF transfection & IC & {$[86]$} \\
\hline 2011 & Qiu & STZ rat & Allogeneic BMSC & None & IC & [87] \\
\hline 2012 & Qiu & STZ rat & Allogeneic BMSC & VEGF transduction & IC & [88] \\
\hline 2012 & Sun & STZ rat & Allogeneic BMSC & None & IC & {$[89]$} \\
\hline 2012 & Nishimatsu & STZ rat & Allogeneic ADSC & None & IC & {$[90]$} \\
\hline 2012 & Ryu & STZ mouse & Syngeneic SVF & None & IC & {$[91]$} \\
\hline 2013 & $\mathrm{He}$ & STZ rat & Allogeneic BMSC & KCNMA1 transduction & IC & {$[92]$} \\
\hline 2013 & Liu & STZ rat & Human ADSC & VEGF transduction & IC & [93] \\
\hline
\end{tabular}

${ }^{*}$ For enhancing stem cell's therapeutic efficacy.

\# Possibly BMMNC.

mesenchymal. Because mesenchymal SCs (MSCs) are by far the most frequently used cell types in SC-for-ED research, some of their characteristics relevant to ED research are discussed below.

MSCs have the potential to differentiate into mesenchymal tissues, such as bone, cartilage, and fat. They were first identified in the bone marrow but have now been shown to exist in virtually all postnatal tissues, including skeletal muscle and adipose tissue $[115,116]$. MSCs have also been consistently localized to the vicinity of blood vessels, and, therefore, the term "perivascular" has been used to denote MSC's tissue location [115, 116]. While "perivascular" can mean near but outside of blood vessels, our investigation of the tissue location of ADSCs indicated that they reside in the capillaries and in the adventitia of blood vessels [117]. Thus, in that paper's Discussion section we proposed the term "vascular stem cells (VSCs)" to denote ADSCs. Since then, several other research groups and a more recent study of ours have confirmed the adventitial localization of ADSCs [118122]. Thus, based on these ADSC studies and many other MSC studies, we have recently redefined MSCs as VSCs, and we also defined VSCs as "cells that reside within the blood vessel wall and can differentiate into all of the cell types that constitute a functional blood vessel" [123]. Based on this definition, VSCs can differentiate into pericytes, smooth muscle, and endothelial cells, which are then assembled into mature blood vessels, during angiogenesis or neovasculogenesis within any particular tissue. Additionally, during normal tissue cycling and in times of tissue injury, VSCs can also differentiate into tissue-specific cells (e.g., adipocytes) so as to maintain tissue homeostasis and to replace lost cells.

MSC's multipotent differentiation potential is what initially attracted interests to this field of research. However, up to this date, it remains controversial whether cellular differentiation is truly responsible for MSC's therapeutic efficacy. First, it is important to know that virtually all claims of MSC's differentiation potential are based on in vitro evidence. In fact, the International Society for Cellular Therapy (ISCT) recommended using chemical or immunohistochemical (IHC) staining of cultured MSCs as a means to demonstrate their differentiation potential [124]. As such, while numerous MSC studies have fulfilled this in vitro criterion, relatively few have investigated whether MSCs do indeed differentiate into particular cell types after transplantation into a host. In the few studies that did conduct such investigations, the results are either utterly negative or kind-of positive [125]. Such difficulties in recognizing MSC's in vivo differentiation potential are mainly due to the lack of specific MSC markers and the unreliability of current cell-tracking labels, as discussed in our recent review article [126].

The ISCT also recommended that MSCs be verified by flow cytometric analysis for expression of cell surface 
TABle 4: Published studies of stem cell therapy for cavernous nerve injury erectile dysfunction.

\begin{tabular}{|c|c|c|c|c|c|c|}
\hline $\begin{array}{l}\text { Publication } \\
\text { year }\end{array}$ & First author & $\mathrm{CN}$ injury method ${ }^{\#}$ & Stem cell type & Modification/supplementation* & Transplantation route & Reference \\
\hline 2004 & Bochinski & Crush & Allogeneic ESC & BDNF transduction & IC or intra-MPG & {$[94]$} \\
\hline 2006 & Kim & Transection & Allogeneic SkMSC & None & IC & {$[95]$} \\
\hline 2009 & Fall & 5-mm resection & Allogeneic BMMNC & None & IC & {$[96]$} \\
\hline 2010 & Albersen & Crush & Autologous ADSC & None & IC & [97] \\
\hline 2010 & Kendirci & Crush & Allogeneic BMSC & p75LNGFR selection & IC & {$[98]$} \\
\hline 2011 & Lin & 5-mm resection & Autologous ADSC & None & Nerve graft & [99] \\
\hline 2011 & Woo & Transection & Allogeneic SkMSC & None & IC & {$[100]$} \\
\hline 2012 & Fandel & Crush & Autologous ADSC & None & IC & {$[101]$} \\
\hline 2012 & Kim & Crush & Allogeneic BMSC & BDNF transduction & Intra-MPG & {$[102]$} \\
\hline 2012 & Kovanecz & 5-mm resection & Mouse SkMSC & Oral sildenafil & IC & {$[103]$} \\
\hline 2012 & Piao & Crush & Human ADSC & BDNF PLGA & CN scaffold & {$[104]$} \\
\hline 2012 & Qiu & Radiation & Allogeneic ADSC & None & IV & {$[105]$} \\
\hline 2012 & Qiu & Crush & Autologous SVF & None & IC & {$[106]$} \\
\hline 2013 & Jeong & Crush & Human ADSC & $\begin{array}{l}\text { BDNF PLGA } \\
\text { Oral udenafil }\end{array}$ & CN scaffold & {$[107]$} \\
\hline 2013 & Kim & Crush & Human ADSC & NGF hydrogel & CN scaffold & {$[108]$} \\
\hline 2013 & You & Not described & Human BMSC & None & $\mathrm{IC}+$ Periprostatic & {$[109]$} \\
\hline 2013 & You & Stretch & Human ADSC & None & $\mathrm{IC}+$ Periprostatic & {$[110]$} \\
\hline 2013 & Choi & Crush & Human testis SC & None & Periprostatic & {$[111]$} \\
\hline 2013 & Ying & Crush & Autologous ADSC & None & IC & {$[112]$} \\
\hline
\end{tabular}

* For enhancing stem cell's therapeutic efficacy.

\# All performed in rats.

markers [124]. Specifically, $\geq 95 \%$ of the population must express CD105, CD73, and CD90, and $\leq 2 \%$ of the population must not express CD45, CD34, CD14 or CD11b, CD79a or CD19, and HLA class II. However, all three recommended positive markers, CD105, CD73, and CD90, are expressed in a wide variety of cells while one of the recommended negative marker, CD34, has proven to be highly useful for the identification and isolation of several MSC types, particularly, ADSCs [127]. In fact, CD34+ bone marrow cells were used to generate the Stro-1 monoclonal antibody $[128,129]$, which has since been used in hundreds of studies for the identification and isolation of a wide variety of MSC types [130, 131]. As such, the ISCT-recommended MSC criteria are in need of a revision.

The scarcity of evidence supporting cellular differentiation as a therapeutic mechanism has prompted considerations for alternative explanations, and presently the leading theory is that MSCs exert therapeutic effects through secretion of paracrine factors [125, 132-134]. Specifically, MSCs have been shown to secrete trophic and immunomodulatory factors that have the potential to (1) stimulate local tissue regeneration, (2) modulate local and systematic inflammatory responses, and (3) mobilize host cells, particularly bone marrow SCs (BMSCs), as repair cells for injured tissues. However, while gaining increasing acceptance, the paracrine theory raises an obvious question: Why not just use the paracrine factors as therapeutic agents? The answer may lie in the fact that MSCs are live cells and therefore capable of responding to host tissue needs, and their paracrine repertoire is obviously much larger and more diverse than single factors. Nevertheless, just like cellular differentiation, paracrine action as a mechanism for MSC's therapeutic effects remains largely unproven. Further details, especially those relevant to SC-for-ED studies, will be discussed in the “Therapeutic Mechanism" section.

\section{Stem Cells Used in Published Erectile Dysfunction Studies}

10.1. Embryonic Stem Cell. ESC has been used in only one SCfor-ED study, and it is the first SC-for-ED study (published in 2004) [94]. The study was conducted in our laboratory and was a very challenging task mainly because of the difficulty in establishing rat ESC in culture [135-137]. In any event, while we finally succeeded in establishing the culture and demonstrated its therapeutic efficacy, ethical concerns about using embryos as a source of therapeutic cells and the emergence of MSCs as substitutes led us to begin exploring ADSC as a more clinically feasible therapeutic agent. Subsequently, we published our first ADSC paper in 2006 [138], and since then we have focused entirely on ADSC as a promising therapeutic agent.

10.2. Bone Marrow Stem Cell. Because MSCs were first identified and isolated from bone marrow, many published 
studies, including several SC-for-ED studies, have simply used the term "MSCs" to denote BMSCs. However, MSCs have now been isolated from many nonbone marrow tissues $[115,116]$; therefore, "BMSCs" should be used as a more discriminative term for bone marrow-derived MSCs. In any event, BMSCs have been investigated in thousands of studies, including 9 SC-for-ED studies, with overall proven therapeutic efficacy. However, it should be noted that in preclinical studies that use small animals as cell donors, the isolation of BMSCs is commonly done after sacrificing these animals. Therefore, transplantation of BMSCs in such studies is mostly allogeneic and sometimes xenogeneic. This would of course raise immunocompatibility issues, but such issues are rarely addressed. In any event, for clinical applications, which are likely to employ autologous transplantation, the preparation of BMSCs requires bone marrow aspiration and several weeks of cell culture/expansion [139].

10.3. Bone Marrow Mononuclear Cell. A preclinical ED study employed BMMNCs to treat CN injury ED [96]. The cells were harvested from donor rats and injected into ED rats without characterization; therefore, their relevance to SC research cannot be determined with certainty. However, the authors hinted at such relevance by stating in the paper's Introduction that "bone marrow is a well-established source of multipotent stem cells..., including mesenchymal stem cells, endothelial progenitor cells, and hematopoietic stem cells." Furthermore, while heterogeneous in cell composition, BMMNCs can be reasonably expected to contain some SCs. Thus, despite lacking experimental evidence for SC relevance, the study is included for discussion in this SC-focused review article. More importantly, this preclinical study apparently provided the scientific basis for the afore-mentioned French clinical trial (Identifier: NCT01089387) that is currently recruiting patients.

10.4. Endothelial Progenitor Cell. Endothelial progenitor cell (EPC) has been used or claimed to have been used in one SCfor-ED study [86]. However, EPC is concerned with several outstanding issues that are important to both ED and non-ED research; therefore, despite being used in only one SC-for-ED study, EPC will be discussed at a disproportional length.

EPC was first reported as circulating blood cells that display endothelial-specific cell surface markers [140]. In recent years, both its relevance to ED and its identity as a SC type have been controversial. In regard to its ED relevance, several studies have shown that ED patients had a reduced number of circulating EPC [141-145], and another study even suggested that boosting EPC number through dietary supplementation could enhance erectile function [146]. However, three studies from another research team have found the opposite; that is, ED patients had higher numbers of circulating EPC [147-149]. These latter studies thus suggested that the discrepancy might be due to differences in the immunophenotypes that were used to evaluate the identity of the isolated EPCs. However, the actual reason is more likely due to uncertainties about what EPC really is $[150$, 151]. For example, it has been shown that EPC might be monocytes contaminated with platelet microparticles [152], or they might be injured or senescent vascular endothelial cells that slough into the bloodstream [153]. Regardless, accumulating evidence has shown that different EPC subsets are in fact various hematopoietic lineage cells; thus, it has been suggested that the term EPC be retired $[154,155]$.

In the one and only EPC-for-ED study, the so-called EPCs were isolated from the bone marrow, not the expected circulating blood. Furthermore, in the study's Methods section, the isolated bone marrow cells were called "mononuclear cells," and the cited studies also suggest that the cells were BMMNCs. One of these studies is titled "Endothelial progenitor cells: identity defined?" [156], and another study concludes: "the adult EPCs we find so far may be mononuclear/macrophages." [157] Thus, despite being called EPCs, the cells used in this ED study are likely BMMNCs.

10.5. Umbilical Cord Blood Stem Cell. Umbilical cord blood SC (UCBSC) has been used in only one SC-for-ED study, and it is a clinical study, the only published clinical study [80]. However, umbilical cord blood is known to contain both hematopoietic and mesenchymal SCs [158], and based on the following considerations, the UCBSC in this study is most likely MSC. First, the cells were provided by a company (also partaking in the study) that commercializes umbilical cord blood-derived MSCs. Second, one of the described characteristics of these cells was their being CD34-. Third, MSC's characteristics were addressed extensively in the report's discussion. Forth, in a recent study in which the same company was involved, the cells were clearly described as umbilical cord blood-derived MSCs [159].

10.6. Skeletal Muscle-Derived Stem Cell. Three ED studies have used skeletal muscle-derived stem cells (SkMSCs) as treatment cells. The first study isolated such cells from rats [95] while the two more recent studies from mice $[82,103]$. These cells were all used to treat ED in rat models; therefore, the transplantation was xenogeneic in the two more recent studies. In one of these two studies [82], the reason for choosing mice over rats as cell donor was "these (mouse) MDSCs are the only ones prepared by this method that have been extensively characterized as stem cells." However, rat SkMSCs isolated by the same method (see below) were described in the ED study by Kim et al. [95] that was published 2 years earlier. And, several urology-related papers that employed rat SkMSCs were also published earlier, including two that were published 7 years earlier $[160,161]$. In any event, the same group of researchers still used mouse SkMSCs to treat ED in rats in their more recent study [103], this time giving no reason.

The cell isolation method used in all three SkMSC-forED studies is termed "preplating," meaning the selection of SkMSCs through several rounds of cell seeding (plating) in plastic cell culture flasks. Only cells that do not adhere in one particular round are seeded in the next round, because early adhering cells (1st and 2nd rounds) have been shown to be more fibroblastic whereas late adhering cells (5th and 6th rounds) more myogenic [160, 161]. Thus, for 
clinical applications, which are likely to employ autologous transplantation, the preparation of a sufficient number of SkMSCs requires several weeks of cell seeding, culturing, and expansion [162].

10.7. Adipose-Derived Stem Cell. ADSC is now the most frequently used cell type in SC-for-ED research, with 18 studies versus 9 for the second-place BMSC. The principal reasons for such an increased interest in ADSC are (1) its overall proven similarities with BMSC, (2) its overall proven therapeutic efficacy across medical disciplines, (3) its abundant tissue source, (4) its ease of isolation, and (5) the availability of automated isolation devices.

The first demonstration of adipose-derived stromal cells as SCs is generally credited to a study published in 2001 by Zuk et al. [163]. But, the fact is that one year earlier Halvorsen et al. [164] already showed that such cells could be induced to express adipocyte- and osteoblast-specific proteins. Nevertheless, Zuk's study is far more thorough in the experimental approach and far more convincing in the outcome data; thus, it indeed deserves being commonly referred to as the first ADSC paper. Still, it should be pointed out that in 2001, there were 5 other ADSC publications [165169 ], and they too need to be acknowledged as pioneering studies in this field of research.

The isolation of ADSC involves a centrifugation step that results in the separation of the stromal vascular fraction (SVF) from the rest of the adipose tissue homogenate. The SVF, which appears as a pellet in the centrifuge tube, contains endothelial cells, smooth muscle cells, pericytes, fibroblasts, mast cells, and preadipocytes [170]. Culturing of SVF cells under standard conditions (i.e., in Dulbecco modified essential medium) eventually (within 2-3 passages) results in the appearance of a relatively homogenous population of mesenchymal cells that are now commonly called ADSC (or ASC, which is recommended by the International Fat Applied Technology Society but can be confused with ASC for adult stem cells). Thus, the relationship between SVF cells and ADSCs is similar to that between BMNNCs and BMSCs, as discussed earlier.

While cultured ADSCs have been used in most SC-forED studies, uncultured SVF cells have been increasingly tested as therapeutic agents. The reasons are mainly the emergence of machines that can rapidly process a human lipoaspirate into SVF cells and reports that such cells are as effective as ADSCs in experimental therapies. However, when considering cell dosage for transplantation, it is important to know that, from one gram of fat, the SVF pellet contains approximately 250,000 cells, but only $2 \%$ of these cells can adhere to plastic culture dish and be further propagated to become the eventual ADSC [171].

10.8. Testis-Derived Stem Cell. A recently published study demonstrated the isolation of SCs from human testis [111]. These cells were positive for CD34 and localized to the testicular stroma; therefore, they are most likely MSCs. However, while it would seem more logic to use these cells for infertility treatment, the study chose CN injury ED instead. In any event, the authors stated that these cells might represent a promising new autologous cell source for clinical use. But, it remains to be seen whether patients will be willing to sacrifice portions of their testicles for the treatment of their ED.

\section{Stem Cell Modification}

A few studies have tested SCs that were transduced or transfected with genes known to encode proteins that positively regulate erectile function $[81,86,88,92-94,102]$. Transfection with plasmids results in cells that only transiently express the transfected gene while transduction requires using a viral vector and a lengthy process to select for positively transduced cells [172]. Therefore, the implementation of transfected or transduced SCs in clinical trials will require preclinical demonstration of highly significant benefits when compared to their untransfected counterparts. Whether this has been accomplished in ED research will be discussed in the "main therapeutic outcomes" section.

\section{Stem Cell Labeling}

For the purpose of tracking SCs after their transplantation, various compounds or genes have been used as cell labels. However, every label has its shortcomings, as discussed in detail in our recent review [126]. Briefly, the use of LacZ gene, which encodes bacterial $\beta$-gal, is hampered by endogenous expression of $\beta$-gal in mammalian tissues. The use of GFP gene, which encodes a green fluorescence protein, is troubled by autofluorescence in mammalian tissues. DAPI, a DNA labeling dye, binds DNA noncovalently; therefore, it can leak from transplanted cells to host cells. DiI, a cell membrane labeling dye, binds to cell membrane noncovalently; therefore, it can also leak from transplanted cells to host cells. BrdU is a thymidine analog, and its detection requires harsh treatment of tissue samples. Therefore, cellular proteins can no longer be detected by IHC or immunofluorescence (IF) due to loss of antigenicity. EdU is a newer thymidine analog that requires no special tissue treatment for detection; therefore, costaining by IHC or IF for cellular proteins is feasible. However, similar to the situation with BrdU, longterm detection of transplanted cells is possible only if the cells are relatively quiescent, as the label gets diluted with each round of cell replication.

\section{Immunocompatibility}

In preclinical studies that employ rats or mice as disease models, transplantation of SCs is most commonly allogeneic. This is due to the following: (1) allogeneic transplantation requires $\mathrm{SC}$ isolation from as few as one animal whereas autologous transplantation requires SC isolation from each test animal and (2) vital tissues such as bone marrow and skeletal muscle cannot be harvested in sufficient quantities for autologous SC preparation without seriously harming the animals. In the case with ADSC, despite its more abundant harvestable tissue source than BMSC or SkMSC, increasingly more studies are conducting xenogeneic transplantation, 
nonetheless, and the donor species has been exclusively humans [173]. The reason is obviously the high availability of adipose tissues that are removed from millions of patients who elect to undergo liposuction or lipectomy. In any event, whether allogeneic or xenogeneic, studies that performed such transplantations usually do not talk about the immunocompatibility issue [173]. Thus, it cannot be certain whether the investigators were unaware of or chose to ignore such issues.

The immunocompatibility issue can actually be addressed easily by citing certain published studies that focused on MSC's immunogenicity. For example, we have recently published a review article on MSC's immunocompatibility issues [173], and although the MSC in question is ADSC, the discussion is actually applicable to all MSCs. This review article itself or some of its referenced studies can be cited to explain why MSCs can be transplanted allogeneically or xenogeneically in immunocompetent recipients without the use of immunosuppressants. Briefly, MSCs have been rather consistently shown to possess immunosuppressive and immunomodulatory properties, and there is also convincing evidence that MSCs do not express major histocompatibility complex-II and therefore elicit no immune reaction when transplanted allogeneically or xenogeneically. For concerns that animal studies may not translate into human outcomes, a recently published phase $1 / 2$ clinical study [174] can be a helpful reference. In this study, 30 patients with ischemic cardiomyopathy were equally randomized into an allogeneic and an autologous groups for transendocardial BMSC injection. The resulting findings are (1) a satisfactory safety profile for both groups, (2) improvement in structural and functional cardiac measures for both groups, and (3) low $(3.7 \%)$ alloimmune reactions in patients receiving allogeneic MSCs.

\section{Stem Cell Transplantation}

IC injection of erectogenic agents is a well-established method to induce erection in ED patients; therefore, in the first SC-for-ED study we tested whether IC injection of SCs could treat $\mathrm{CN}$ injury ED in rats [94]. Meanwhile, because CNs originate from MPG, we also tested intra-MPG injection of SCs. As the results showed that both transplantation routes were equally effective in treating $\mathrm{CN}$ injury $\mathrm{ED}$, and due to the fact that IC injection is easier to perform than intra-MPG injection, IC injection has become the preferred method for the transplantation of SC into $\mathrm{CN}$-injury and other types of ED animal models ( 25 out of 35 studies). However, it should be pointed out that $\mathrm{CN}$ injury causes pathological changes in the MPG; therefore, for treating CN injury, IC injected SCs need to be able to migrate to the MPG and/or release soluble factors that can reach the MPG via blood flow. Such therapeutic mechanisms have received supports from our studies that showed (1) IC injected ADSCs can migrate to the MPG in response to CN injury [101, 175], (2) cultured ADSCs abundantly secrete CXCL5 cytokine, and (3) CXCL5 possesses both angiogenic and neurotrophic properties [176, 177].
As intra-MPG injection is less clinically feasible than IC injection, it has not been used again until recently in which CN injury ED was the treatment target [102]. While positive outcomes were reported, no reason was given as to why choosing this more difficult injection method. In any event, the same group of researchers also tested other transplantation methods in three additional $\mathrm{CN}$ injury ED studies. Specifically, SCs were applied to the injured CNs and then covered with a scaffold material of either poly(lacticco-glycolic acid) (PLGA) or hydrogel [104, 107, 108]. While positive outcomes were observed, it is presently unknown whether this scaffold approach is better than IC injection in terms of treatment efficacy. In three other $\mathrm{CN}$ injuryED studies by two other research groups, SCs were injected periprostatically with $[109,110]$ or without $[111]$ concomitant IC injection. Direct comparison showed that periprostatic and IC injections produced similar therapeutic effects, but concomitant periprostatic and IC injections did not produce better outcomes than either injection alone [110].

Autologous nerve graft has been tested for the repair of damaged CN $[178,179]$. However, the harvest of autologous nerves causes donor site morbidity. Thus, in a recently published study we tested whether acellular matrix seeded with SCs can be used as a nerve graft for CN repair [99]. Specifically, based on consideration that large quantities of adipose tissue are routinely removed from plastic surgery patients, we proposed that such "medical wastes" could be processed into acellular matrix for the seeding of ADSCs. Grafting of the seeded matrix to repair resected CNs resulted in improved erectile function that slightly missed statistical significance $(P<0.07$, due to large variations). Thus, we believe that the approach is feasible but requires improvements in fabrication of the acellular matrix.

We have previously shown that both intraorgan (urinary bladder or urethra) and intravenous (IV) injections of ADSCs improved urinary function in rat models of stress urinary incontinence and detrusor overactivity [180, 181]. In a more recent study we showed that IV injection of ADSC also improved erectile function in post-RT ED rats [105]. Thus, IV injection appears to be a feasible option for SC transplantation.

TA reconstruction with grafts is often performed on PD patients with large plaques. However, the procedure is associated with postoperation complications, such as ED. In a recent study, TA reconstruction with ADSC-seeded SIS was found to have a lower rate of ED complication than using unseeded SIS [78]. In another recent study, ADSC was injected into the TA that was undergoing fibrotic changes due to a prior TGF- $\beta$ injection [79]. This intratunical ADSC injection resulted in significantly less TA fibrosis and better erectile function when compared to intratunical saline injection.

\section{Functional Assessment}

Whether SC treatment improves erectile function is most commonly assessed at 4 weeks after treatment by measurement of intracavernous pressure (ICP) in response to 
electrostimulation of CN. Such stimulation mimics sexual stimulation and causes an increase of ICP that can approach systemic blood pressure. In fact, to account for variations in individual animal's systemic blood pressure, ICP is often normalized to mean arterial pressure (MAP). Thus, after the animal is anesthetized, a $25 \mathrm{G}$ needle connected to a heparinfilled PE-50 tubing is inserted into the aortic bifurcation, the carotid artery, or the femoral artery for the measurement of MAP, and another similarly connected $25 \mathrm{G}$ needle is inserted into the crura for the measurement of ICP. The MAP and ICP values are acquired via a pressure transducer connected to a data acquisition system. Electrostimulation is applied through a stainless steel bipolar hook placed on the $\mathrm{CN}$ approximately $5 \mathrm{~mm}$ distal to the MPG. Electricity is typically applied at a fixed frequency of $20 \mathrm{~Hz}$, pulse width of $0.2 \mathrm{~ms}$, and duration of 50 seconds. Three different amperage settings of $0.5,1$, and $1.5 \mathrm{~mA}$ are typically tested to obtain a range of erectile responses, and in between stimulations a rest period of 5-10 min is allowed for the $\mathrm{CN}$ to recover.

\section{Histological Assessment}

The above-described functional assessment requires laparotomy followed by sacrificing the animal. The sacrificed animal is then subjected to the harvest of the penis, MPG, and any other tissues of interest. These tissues are then assessed histologically by IHC, IF, and/or chemical staining. In the penis, IHC or IF staining is routinely used to assess the three key structures that regulate penile erection, namely, CEC, CSMC, and CN. The most commonly used markers for CEC are CD31, eNOS, RECA-1, and vWF. CN is mostly commonly evaluated by IHC or IF staining for the expression of nNOS in the dorsal nerves. For CSMC, the most commonly used method is IHC or IF staining for -smooth muscle actin. However, we have recently reported that staining with Alexa fluor-conjugated phalloidin was easier and quicker, and the resulting images were superior [18]. Masson's trichrome staining has also been commonly used to assess CSMC although the resulting red stains actually represent not only CSMC but also CEC, fibroblasts, and any other cells. For PD-related studies, the assessment of TA is usually done by trichrome staining or by IHC or IF staining for collagen-I and elastin. For studies using $\mathrm{CN}$ injury models, the examination of MPG is usually accomplished by IHC or IF staining for S100, neurofilaments, or other neural markers.

A few earlier SC-for-ED studies have attempted to identify transplanted SCs through histological examination of penile tissues. However, molecules or agents that were used to prelabel SCs all have inherent shortcomings [126]. In addition, we have shown that IC transplanted SCs quickly disappeared from penile tissues $[101,175]$. As such, few recent studies have reported cell tracking data.

\section{Main Outcomes}

Up to November 2013 a total of 35 SC-for-ED studies have been published, and 29 of them are concerned with either $\mathrm{CN}$ injury (19 studies) or DM (10 studies). So, the discussion of SC-for-ED studies' main outcomes will be divided according to these two types of ED.

17.1. Diabetic ED. The first such studies were published in 2010, both dealing with T2DM, with one being clinical trial and the other preclinical. The clinical trial was carried out in Korea and involved treating each of seven T2DM patients (57 to 87 years of age) with IC injection of 15 million allogeneic UCBSCs [80]. At one month after treatment, three patients regained morning erection, and at 3 months, three additional patients regained morning erection. However, despite having increased penile rigidity, these patients were still unable to achieve vaginal penetration unless taking sildenafil before coitus. Nevertheless, at 11-month follow-up, one patient was able to maintain sufficient erection for coitus. Interestingly, all patients except the oldest had reduced levels of blood glucose and glycosylated hemoglobin, suggesting SC therapy might have antidiabetes effects, and supporting our observation that IC injection is a systemic application (see Stem Cell Transplantation).

The preclinical study was conducted by our group [85] and it utilized the ZDF rats, which were found to develop T2DM within the first 10 weeks of age and to develop ED at 22 weeks of age. These T2DM-ED rats were randomized for treatment with IC injection of autologous ADSC or with saline. Three weeks later, the ADSC-treated rats were found to have significantly higher ICP/MAP values than the salinetreated rats. Histological examination of erectile tissue also found that ADSC-treated rats had lower levels of apoptosis and higher numbers of endothelia cells and nNOS-positive nerves.

Apart from the two studies mentioned above, all SC-fordiabetic ED studies employed STZ-induced T1DM animal models. In one of two studies published in 2011, Gou et al. [86] reported using IC injection of VEGF-transfected allogeneic EPC to treat diabetic ED in rats. While the cell may actually be BMMNC (see Endothelial Progenitor Cell), ICP values obtained at 3 weeks after treatment were 56.22, 20.46, and 20.24 for rats treated with VEGF-transfected cell, blank vector-transfected cell, and untransfected cell, respectively. However, it should be noted that there were no normal or untreated controls; therefore, it cannot be determined whether the ICP value of 56.22 indicates treatment efficacy, or whether the ICP values of 20.46 and 20.24 indicate treatment inefficacy. It should also be pointed out that the SCs were transfected with a VEGF-expressing plasmid; therefore, they cannot be expected to maintain VEGF expression.

In the other 2011 study Qiu et al. [87] employed IC injection of allogeneic BMSC, and ICP/MAP values obtained four weeks later were $0.8,0.6$, and 0.4 for normal (nondiabetic), BMSC-treated, and untreated rats, respectively. In 2012, the same team of researchers published a similar study, this time adding a group of rats treated with VEGF-transduced BMSC [88]. The resulting ICP/MAP values were $0.82,0.59,0.48$, and 0.36 for normal (nondiabetic), VEGF-BMSC-treated, BMSC-treated, and untreated rats, respectively. Therefore, the two studies had similar ICP/MAP values for both 
the positive (nondiabetic) and negative (untreated diabetic) controls. However, the ICP/MAP value for the BMSC-treated group changed from 0.6 in 2011 to 0.48 in 2012 . Thus, this discrepancy needs to be resolved before a conclusion can be made on whether VEGF transduction indeed improved therapeutic efficacy.

Three additional studies were published in 2012. Nishimatsu et al. [90] demonstrated that the therapeutic effects of IC injected allogeneic ADSC's were mediated by adrenomedullin. The study by Sun et al. [89] is unusual in that an emphasis was placed on $\mathrm{CN}$ nerve regeneration (as opposed to endothelial preservation or restoration) as the therapeutic mechanism for IC injected BMSC in a diabetic ED animal model. The study by Ryu et al. [91] is unique in that the animal model was murine and the treatment cell was syngeneic SVF. More importantly, this study tested SVF cells at three different dosages. While 10,000 cells had no effects, 100,000 and 200,000 improved ICP to $82 \%$ of normal control. Such data is valuable in that they validated the importance of SC and identified a potential optimal dosage.

Two studies were published in 2013. He et al. [92] reported that BMSC transduced with KCNMA1 (a potassium channel) was better than untransfected BMSC. Liu et al. [93] showed that VEGF-transduced ADSC was better than untransfected ADSC.

17.2. CN-Injury ED. The first such study transplanted BDNFtransduced ESC into a CN crush injury rat model by either IC or intra-MPG injection [94]. Erectile function was assessed by ICP measurement at 3 months, and the resulting peak ICP values (in $\mathrm{cmH}_{2} \mathrm{O}$ ) were 96.9 for sham-treated group, 30.5 for untreated group, 55.1 for intra-MPG group, and 54.1 for IC group. While both treated groups were significantly better than the untreated group, there was no significant difference between the two treated groups. Histological analysis outcomes paralleled erectile functional outcomes.

The second study transplanted allogeneic SkMSC into a $\mathrm{CN}$ transection injury rat model by IC injection [95]. Functional analyses at 2 and 4 weeks both showed significantly better ICP values in treated versus untreated groups. The third study transplanted allogeneic BMMNC into a $5 \mathrm{~mm} \mathrm{CN}$ resection injury rat model by IC injection [96]. Functional analyses at 3 and 5 weeks both showed significantly better ICP values in treated versus untreated groups.

Two CN crush injury studies were published in 2010. One emphasized on comparing between allogeneic BMSC and a specific population of allogeneic BMSC that was selected for cell surface expression of p75 low affinity nerve growth factor receptor (p75LNGFR) [98]. The other was interested in comparing between autologous ADSC and cell lysate that was prepared from autologous ADSC [97]. Functional and histological analyses at 4 weeks showed that p75LNGFR-selected BMSC was significantly better than unselected BMSC, and ADSC and ADSC lysates were equally effective in treating $\mathrm{CN}$ crush injury ED. Two additional studies were published in 2011. One is similar to the abovementioned 2006 study [95], as acknowledged in its discussion, in that the same animal model (CN transection), same SC type (SkMSC), and same injection route (IC) were employed, and similar functional outcome (ICP value) obtained [100]. The other is unique in that SC was employed as seeded cells on an acellular matrix, which was then grafted to repair a $5 \mathrm{~mm}$ gap in resected CNs [99]. The functional outcomes were favorable but slightly missed statistical significance.

Six CN injury studies were published in each of 2012 and 2013. Three of the 2012 studies are from our group. First, Fandel et al. [101] provided the first evidence that IC injected SCs (autologous ADSCs in this case) rapidly disappeared from the injection site and migrated to MPG in $\mathrm{CN}$ injury rats. Second, Qiu et al. [105] for the first time established a post-RT ED as target for SC therapy and also for the first time used IV injection for SC transplantation. Third, for the first time we showed that IC injection of SCs (autologous SVF cells in this case) was able to treat both acute (immediate) and chronic (4 weeks) CN injury-induced ED [106]. This study is also the first to examine functional and histological outcomes at 3 months post-SC injection, instead of the more commonly chosen one-month time point.

The remaining three 2012 studies all investigated combinatory SC therapy. Kovanecz et al. [103] showed that IC injection of SkMSC (xenogeneic mouse cells) alone or in combination with oral sildenafil was able to normalize erectile function in CN injury rats, but the combination of SkMSC with sildenafil was not superior to SkMSC or sildenafil alone. Kim et al. [102] employed intra-MPG injection of BDNFtransduced allogeneic BMSCs; the results showed that both BMSC and BDNF-BMSC were efficacious, but the latter was better. Piao et al. [104] employed BDNF-immobilized PLGA membrane with and without ADSC (xenogeneic human cells); the results showed that the combinatory treatment was better than single-agent treatments.

The same research group that conducted the abovementioned BDNF-BMSC and BDNF-ADSC studies published two additional CN-injury studies in 2013. The one by Jeong et al. [107] is essentially the same as Piao et al. [104], except for adding a third treatment agent, udenafil, which is a newly developed PDE5I. The other by Kim et al. [108] used NGF instead of BDNF and hydrogel instead of PLGA. In any event, all four studies conducted by this research group (2 each in 2012 and 2013) indicated that any tested agent, whether BMSC, ADSC, BDNF, NGF, hydrogel, PLGA, or udenafil, was able to provide an additional level of therapeutic efficacy.

In two separate studies $[109,110]$, You et al. tested human BMSC and human ADSC (thus, both were xenogeneic), respectively, for treatment of $\mathrm{CN}$-injury $\mathrm{ED}$ in rats. These studies' novelty was the hypothesis that a combination of IC and periprostatic injections might be better than IC or periprostatic injection alone. But, while the BMSC study obtained results that supported this hypothesis, the ADSC study did not.

Choi et al. [111] recently reported the isolation of MSCs from human testes. While such cells would seem suited for treating infertility, they were tested in a $\mathrm{CN}$ injury rat $\mathrm{ED}$ model. In any event, the results showed that these cells were as effective as BMSCs in preserving erectile function, and this led the authors to conclude that these cells might represent 
a promising new autologous cell source for clinical use. However, it should be pointed out that in this study the SC was xenogeneic, not autologous, and if indeed future clinical application of this SC will be done autologously, patients may have difficulty deciding whether excision of their testicle tissue for SC isolation is acceptable.

The last CN injury study [112] to be discussed here performed functional and histological assessments at 3 months after IC injection of ADSC. Thus, it reinforced our earlier observation [106] that a single-bolus IC injection of autologous ADSC could preserve erectile function for a prolonged period.

\section{Therapeutic Mechanism}

MSC's therapeutic capacity has been demonstrated across all medical disciplines, but how they exert such effects remains poorly understood. As mentioned earlier in the "Stem Cell Basics" section, two seemingly opposing mechanisms, cellular differentiation and paracrine action, have been considered. For cellular differentiation as a therapeutic mechanism, direct evidence has been scarce, and the difficulty in obtaining such evidence lies with the fact that cell-tracking labels are unreliable [126] and transplanted SCs rapidly disappear from the injection site $[101,175]$. Thus, most SC-for-ED studies have come to the conclusion that paracrine action was responsible for their SC's therapeutic effects. However, direct evidence for paracrine action as a therapeutic mechanism is similarly scant, as summarized below.

Kendirci et al. [98] found that rat BMSC abundantly secreted basic fibroblast growth factor in culture. Albersen et al. [97] showed that lysate preparation from ADSC was just as good as intact ADSC in repairing $\mathrm{CN}$ injury. And, Zhang et al. $[176,177]$ found that rat ADSC abundantly secreted CXCL5 in culture, and this cytokine had potent angiogenic and neurotrophic activities. Thus, these four studies provided indirect or suggestive evidence for paracrine action as a therapeutic mechanism. On the other hand, the study by Nishimatsu et al. [90] provided direct evidence by using siRNA to knock down the expression of adrenomedullin in ADSC and demonstrating that such ADSC had reduced ability to preserve erectile function in diabetic ED rats. However, it must be pointed out that in this study, ADSCs with or without adrenomedullin knockdown were cultured in a medium specifically formulated for endothelial cells, and we have shown that ADSCs cultured in this medium spontaneously differentiated into endothelial cells [182]. Therefore, while providing direct evidence for paracrine action as a therapeutic mechanism, the study might have unintentionally employed endothelially induced ADSC rather than regular (uninduced) ADSC. In another study by Ryu et al. [91] VEGF neutralizing antibody was injected subcutaneously immediately before IC injection of SVF cells in STZ-induced diabetic ED mice. Such treatment effectively abolished SVF cell-induced angiogenesis in the CC and improvement of erectile function. Thus, apart from the fact that SVF cell preparation is a mixture of ADSCs and non-SCs, this study can be considered as providing solid direct evidence for paracrine action as a mechanism for SC's therapeutic effects.

\section{Conclusion}

SC therapy for ED has been investigated in 34 preclinical studies and one clinical trial. In responding to clinical needs, 19 of these studies targeted $\mathrm{CN}$ injury ED and 10 diabetic ED. ADSC is the most commonly employed SC, likely due to its ease of isolation from an abundant tissue source. However, deviating from expected clinical practices, allogeneic and xenogeneic SCs have increasingly been used in these studies. The reasons are (1) autologous SCs must be isolated from each tested animal, and this usually means more than 30 SC preparations in a typical preclinical study, (2) only one SC preparation is needed for allogeneic or xenogeneic transplantation, and it can even be obtained through purchase, and (3) the abundance of lipoaspirates produced from plastic surgeries has encouraged the use of human ADSC as a convenient SC source. Regardless of the reason, when allogeneic or xenogeneic SCs are used, their immunocompatibility issue should be properly addressed.

In more recent studies, SCs tend to be modified by transfection with angiogenic or neurotrophic genes, or their transplantation supplemented with such growth factors. While these modifications and supplementations were usually reported to increase therapeutic efficacy, the degree of improvement has always been small. So, it remains to be seen whether the benefit can outweigh the risk when it comes to clinical applications. Regardless, SC transplantation has mostly been done by IC injection, but more recent studies tend to try alternative routes, such as IV injection, periprostatic injection, and scaffolding. However, with few head-on comparisons with IC injection, it remains uncertain whether these alternatives are more advantageous.

All 35 studies reported improved erectile function with SC transplantation in ED patients or animal models. But the improvement as determined by ICP measurement is usually around $70 \%$ when compared to non-ED controls. Thus, it remains to be seen whether this level of improvement is sufficient for ED patients to successfully perform intercourse. In some preclinical studies SC transplantation also resulted in improved muscle, endothelium, and/or nerve in the erectile tissue, but few of these studies reported differentiation or engraftment of the transplanted SCs. Thus, authors of these studies often stated that paracrine action was likely responsible for SC's therapeutic effects. However, while convenient, such a hypothesis has received little support from actual investigations. Therefore, in terms of improving our understanding of how SCs exert their therapeutic effects, there needs to be a shift of research effort from the current preference for functional outcomes toward mechanism findings. For example, if indeed a particular growth factor is believed to be important, it should be investigated by means of specific inhibition or blockade of its action, or by using cell lines or animals that lack its expression. Such tasks are obviously technically challenging, but if successfully 
executed, they can truly advance the field of SC-for-ED research.

$\begin{array}{ll}\text { Abbreviations } \\ \text { ADSC: } & \text { Adipose-derived stem cell } \\ \text { BDNF: } & \text { Brain-derived neurotrophic factor } \\ \text { BMNNC: } & \text { Bone marrow mononucleated cell } \\ \text { BMSC: } & \text { Bone marrow stem cell } \\ \text { CC: } & \text { Corpus cavernosum } \\ \text { CEC: } & \text { Cavernous endothelial cell } \\ \text { CN: } & \text { Cavernous nerve } \\ \text { CSMC: } & \text { Cavernous smooth muscle cell } \\ \text { DM: } & \text { Diabetes mellitus } \\ \text { ED: } & \text { Erectile dysfunction } \\ \text { eNOS: } & \text { Endothelial nitric oxide synthase } \\ \text { EPC: } & \text { Endothelial progenitor cell } \\ \text { IC: } & \text { Intracavernous } \\ \text { ICP: } & \text { Intracavernous pressure } \\ \text { IF: } & \text { Immunofluorescence } \\ \text { IHC: } & \text { Immunohistochemistry } \\ \text { IV: } & \text { Intravenous } \\ \text { MAP: } & \text { Mean arterial pressure } \\ \text { MPG: } & \text { Major pelvic ganglia } \\ \text { MSC: } & \text { Mesenchymal stem cell } \\ \text { NGF: } & \text { Nerve growth factor } \\ \text { NO: } & \text { Nitric oxide } \\ \text { nNOS: } & \text { Neuronal nitric oxide synthase } \\ \text { p75LNGFR: } & \text { p75 low affinity nerve growth factor receptor } \\ \text { PD: } & \text { Peyronie's disease } \\ \text { PDE5: } & \text { Phosphodiesterase 5 } \\ \text { PDE5I: } & \text { Phosphodiesterase 5 inhibitor } \\ \text { PKG: } & \text { Protein kinase G } \\ \text { PLGA: } & \text { Poly(lactic-co-glycolic acid) } \\ \text { RP: } & \text { Radical prostatectomy } \\ \text { RT: } & \text { Radiation therapy } \\ \text { SC: } & \text { Stem cell } \\ \text { SIS: } & \text { Small intestine submucosa } \\ \text { STZ: } & \text { Streptozotocin } \\ \text { SVF: } & \text { Stromal vascular fraction } \\ \text { T1DM: } & \text { Type 1 diabetes mellitus } \\ \text { T2DM: } & \text { Type 2 diabetes mellitus } \\ \text { TA: } & \text { Tunica albuginea } \\ \text { VSC: } & \text { Vascular stem cell } \\ \text { ZDF: } & \text { Zucker Diabetic Fatty. } \\ & \end{array}$

\section{Conflict of Interests}

The author declares no conflict of interests.

\section{References}

[1] N. C. Panel, "Impotence," NIH Consens Statement, vol. 10, pp. $1-33,1992$.

[2] B. A. Inman, J. L. St. Sauver, D. J. Jacobson et al., "A populationbased, longitudinal study of erectile dysfunction and future coronary artery disease," Mayo Clinic Proceedings, vol. 84, no. 2, pp. 109-113, 2009.
[3] G. Jackson, N. Boon, I. Eardley et al., "Erectile dysfunction and coronary artery disease prediction: evidence-based guidance and consensus," International Journal of Clinical Practice, vol. 64, no. 7, pp. 848-857, 2010.

[4] K. Chew, J. Finn, B. Stuckey et al., "Erectile dysfunction as a predictor for subsequent atherosclerotic cardiovascular events: findings from a linked-data study," The Journal of Sexual Medicine, vol. 7, no. 1, pp. 192-202, 2010.

[5] J. Dong, Y. Zhang, and L. Qin, "Erectile dysfunction and risk of cardiovascular disease: meta-analysis of prospective cohort studies," Journal of the American College of Cardiology, vol. 58, no. 13, pp. 1378-1385, 2011.

[6] G. Wagner, K. S. Fugl-Meyer, and A. R. Fugl-Meyer, "Impact of erectile dysfunction on quality of life: patient and partner perspectives," International Journal of Impotence Research, vol. 12, supplement 4, pp. S144-S146, 2000.

[7] J. J. Sánchez-Cruz, A. Cabrera-León, A. Martín-Morales, A. Fernández, R. Burgos, and J. Rejas, "Male erectile dysfunction and health-related quality of life," European Urology, vol. 44, no. 2, pp. 245-253, 2003.

[8] T. Kushiro, A. Takahashi, F. Saito et al., "Erectile dysfunction and its influence on quality of life in patients with essential hypertension," American Journal of Hypertension, vol. 18, no. 3, pp. 427-430, 2005.

[9] M. S. Sand, W. Fisher, R. Rosen, J. Heiman, and I. Eardley, "Erectile dysfunction and constructs of masculinity and quality of life in the multinational Men's Attitudes to Life Events and Sexuality (MALES) study," The Journal of Sexual Medicine, vol. 5, no. 3, pp. 583-594, 2008.

[10] G. V. Fernandes, R. R. dos Santos, W. Soares et al., "The impact of erectile dysfunction on the quality of life of men undergoing hemodialysis and its association with depression," The Journal of Sexual Medicine, vol. 7, no. 12, pp. 4003-4010, 2010.

[11] A. Avasthi, S. Grover, A. Bhansali et al., "Erectile dysfunction in diabetes mellitus contributes to poor quality of life," International Review of Psychiatry, vol. 23, no. 1, pp. 93-99, 2011.

[12] I. A. Aytaç, J. B. McKinlay, and R. J. Krane, "The likely worldwide increase in erectile dysfunction between 1995 and 2025 and some possible policy consequences," BJU International, vol. 84, no. 1, pp. 50-56, 1999.

[13] A. Melman and K. Davies, "Gene therapy for erectile dysfunction: what is the future?" Current Urology Reports, vol. 11, no. 6, pp. 421-426, 2010.

[14] A. R. McCullough, J. H. Barada, A. Fawzy, A. T. Guay, and D. Hatzichristou, "Achieving treatment optimization with sildenafil citrate (Viagra) in patients with erectile dysfunction," Urology, vol. 60, no. 2, pp. 28-38, 2002.

[15] M. Kendirci and W. J. G. Hellstrom, "Current concepts in the management of erectile dysfunction in men with prostate cancer," Clinical Prostate Cancer, vol. 3, no. 2, pp. 87-92, 2004.

[16] V. Phé and M. Rouprêt, "Erectile dysfunction and diabetes: a review of the current evidence-based medicine and a synthesis of the main available therapies," Diabetes and Metabolism, vol. 38, no. 1, pp. 1-13, 2012.

[17] T. F. Lue, "Erectile dysfunction," The New England Journal of Medicine, vol. 342, no. 24, pp. 1802-1813, 2000.

[18] G. Lin, X. Qiu, T. M. Fandel et al., "Improved penile histology by phalloidin stain: circular and longitudinal cavernous smooth muscles, dual-endothelium arteries, and erectile dysfunctionassociated changes," Urology, vol. 78, no. 4, pp. 970.el-970.e8, 2011. 
[19] X. Qiu, T. M. Fandel, G. Lin et al., "Cavernous smooth muscle hyperplasia in a rat model of hyperlipidaemia- associated erectile dysfunction," BJU International, vol. 108, no. 11, pp. 1866-1872, 2011.

[20] A. Awad, B. Alsaid, T. Bessede, S. Droupy, and G. Benoît, "Evolution in the concept of erection anatomy," Surgical and Radiologic Anatomy, vol. 33, no. 4, pp. 301-312, 2011.

[21] W. G. Dail, D. Trujillo, D. de la Rosa, and G. Walton, "Autonomic innervation of reproductive organs: analysis of the neurons whose axons project in the main penile nerve in the pelvic plexus of the rat," Anatomical Record, vol. 224, no. 1, pp. 94-101, 1989.

[22] C. S. Lin, "Lue TF Cyclic nucleotide signaling in vascular and cavernous smooth muscle: aging-related changes," in Advances in Cell Aging and Gerontology, E. Bittar, Ed., vol. 16, pp. 57-106, Elsevier, 2004.

[23] C. Lin, G. Lin, and T. F. Lue, "Cyclic nucleotide signaling in cavernous smooth muscle," The Journal of Sexual Medicine, vol. 2, no. 4, pp. 478-491, 2005.

[24] C. Lin, Z. Xin, Z. Wang, G. Lin, and T. F. Lue, "Molecular Yin and Yang of erectile function and dysfunction," Asian Journal of Andrology, vol. 10, no. 3, pp. 433-440, 2008.

[25] K. J. Hurt, B. Musicki, M. A. Palese et al., "Akt-dependent phosphorylation of endothelial nitric-oxide synthase mediates penile erection," Proceedings of the National Academy of Sciences of the United States of America, vol. 99, no. 6, pp. 4061-4066, 2002.

[26] T. J. Bivalacqua, M. F. Usta, H. C. Champion, P. J. Kadowitz, and W. J. G. Hellstrom, "Endothelial dysfunction in erectile dysfunction: role of the endothelium in erectile physiology and disease," Journal of Andrology, vol. 24, pp. S17-S37, 2003.

[27] A. L. Burnett, "Novel nitric oxide signaling mechanisms regulate the erectile response," International Journal of Impotence Research, vol. 16, supplement 1, pp. S15-S19, 2004.

[28] G. Corona, L. Petrone, E. Mannucci et al., "Difficulties in achieving vs maintaining erection: organic, psychogenic and relational determinants," International Journal of Impotence Research, vol. 17, no. 3, pp. 252-258, 2005.

[29] H. Wessells, T. H. Teal, K. Engel et al., "Fluid shear stressinduced nitric oxide production in human cavernosal endothelial cells: inhibition by hyperglycaemia," BJU International, vol. 97, no. 5, pp. 1047-1052, 2006.

[30] T. Michel and O. Feron, "Nitric oxide synthases: which, where, how, and why?" The Journal of Clinical Investigation, vol. 100, no. 9, pp. 2146-2152, 1997.

[31] C. Lin, A. Lau, E. Bakircioglu et al., "Analysis of neuronal nitric oxide synthase isoform expression and identification of human nNOS- $\mu$, Biochemical and Biophysical Research Communications, vol. 253, no. 2, pp. 388-394, 1998.

[32] H. Ning, X. Qiu, L. Baine et al., "Effects of high glucose on human cavernous endothelial cells," Urology, vol. 80, pp. 1162. e7-1162. el1, 2012.

[33] C. Lin, "Phosphodiesterase type 5 regulation in the penile corpora cavernosa," The Journal of Sexual Medicine, vol. 6, supplement 3, pp. 203-209, 2009.

[34] C. Lin, G. Lin, Z. Xin, and T. F. Lue, "Expression, distribution and regulation of phosphodiesterase 5," Current Pharmaceutical Design, vol. 12, no. 27, pp. 3439-3457, 2006.

[35] R. Shamloul and H. Ghanem, "Erectile dysfunction," The Lancet, vol. 381, pp. 153-165, 2013.
[36] A. A. Carvalheira, N. M. Pereira, J. Maroco et al., "Dropout in the treatment of erectile dysfunction with PDE5: a study on predictors and a qualitative analysis of reasons for discontinuation," The Journal of Sexual Medicine, vol. 9, pp. 2361-2369, 2012.

[37] National Diabetes Statistics, National Diabetes Information Clearinghouse, National Institute of Diabetes and Digestive and Kidney Diseases (NIDDK), National Institutes of Health, 2011, http://diabetes.niddk.nih.gov/dm/pubs/statistics/index.aspx.

[38] G. Danaei, M. M. Finucane, Y. Lu et al., "National, regional, and global trends in fasting plasma glucose and diabetes prevalence since 1980: systematic analysis of health examination surveys and epidemiological studies with 370 country-years and 2.7 million participants," The Lancet, vol. 378, no. 9785, pp. 31-40, 2011.

[39] IDF Diabetes Atlas, International Diabetes Federation, http://www.idf.org/diabetesatlas/5e/the-global-burden.

[40] R. W. Lewis, K. S. Fugl-Meyer, G. Corona et al., "Definitions/epidemiology/risk factors for sexual dysfunction," The Journal of Sexual Medicine, vol. 7, no. 4, pp. 1598-1607, 2010.

[41] H. A. Feldman, I. Goldstein, D. G. Hatzichristou, R. J. Krane, and J. B. McKinlay, "Impotence and its medical and psychosocial correlates: results of the Massachusetts Male Aging study," Journal of Urology, vol. 151, no. 1, pp. 54-61, 1994.

[42] A. Ponholzer, C. Temml, K. Mock, M. Marszalek, R. Obermayr, and S. Madersbacher, "Prevalence and risk factors for erectile dysfunction in 2869 men using a validated questionnaire," European Urology, vol. 47, no. 1, pp. 80-85, 2005.

[43] V. Fonseca, A. Seftel, J. Denne, and P. Fredlund, "Impact of diabetes mellitus on the severity of erectile dysfunction and response to treatment: analysis of data from tadalafil clinical trials," Diabetologia, vol. 47, no. 11, pp. 1914-1923, 2004.

[44] D. F. Penson, D. M. Latini, D. P. Lubeck, K. L. Wallace, J. M. Henning, and T. F. Lue, "Do impotent men with diabetes have more severe erectile dysfunction and worse quality of life than the general population of impotent patients? Results from the Exploratory Comprehensive Evaluation of Erectile Dysfunction (ExCEED) database," Diabetes Care, vol. 26, no. 4, pp. 1093 1099, 2003.

[45] M. Albersen, G. Lin, T. M. Fandel et al., "Functional, metabolic, and morphologic characteristics of a novel rat model of type 2 diabetes-associated erectile dysfunction," Urology, vol. 78, no. 2, pp. 476.el-476.e8, 2011.

[46] M. R. Dashwood, A. Crump, X. Shi-Wen, and A. Loesch, "Identification of neuronal nitric oxide synthase (nNOS) in human penis: a potential role of reduced neuronally-derived nitric oxide in erectile dysfunction," Current Pharmaceutical Biotechnology, vol. 12, no. 9, pp. 1316-1321, 2011.

[47] F. Zhou, H. Xin, T. Liu et al., "Effects of icariside II on improving erectile function in rats with streptozotocin-induced diabetes," Journal of Andrology, vol. 33, pp. 832-844, 2012.

[48] S. Cellek, N. A. Foxwell, and S. Moncada, "Two phases of nitrergic neuropathy in streptozotocin-induced diabetic rats," Diabetes, vol. 52, no. 9, pp. 2353-2362, 2003.

[49] X. Qiu, G. Lin, Z. Xin et al., "Effects of low-energy shockwave therapy on the erectile function and tissue of a diabetic rat model," The Journal of Sexual Medicine, vol. 10, pp. 738-746, 2013.

[50] C. Costa, R. Soares, Â. Castela et al., "Increased endothelial apoptotic cell density in human diabetic erectile tissuecomparison with clinical data," The Journal of Sexual Medicine, vol. 6 , no. 3, pp. 826-835, 2009. 
[51] H. Ning, G. Lin, T. F. Lue et al., "A coculture system of cavernous endothelial and smooth muscle cells," International Journal of Impotence Research, vol. 25, pp. 63-68, 2013.

[52] K. Park, K. S. Ryu, W. J. Li, S. W. Kim, and J. Paick, "Chronic treatment with a type 5 phosphodiesterase inhibitor suppresses apoptosis of corporal smooth muscle by potentiating Akt signalling in a rat model of diabetic erectile dysfunction," European Urology, vol. 53, no. 6, pp. 1282-1288, 2008.

[53] A. Jemal, R. Siegel, J. Xu, and E. Ward, "Cancer statistics," CA Cancer Journal for Clinicians, vol. 60, no. 5, pp. 277-300, 2010.

[54] J. Brandeis, C. L. Pashos, J. M. Henning et al., "A nationwide charge comparison of the principal treatments for early stage prostate carcinoma," Cancer, vol. 89, pp. 1792-1799, 2000.

[55] R. C. Dean and T. F. Lue, "Neuroregenerative strategies after radical prostatectomy," Reviews in Urology, vol. 7, supplement 2, pp. S26-S32, 2005.

[56] M. Kendirci, J. Bejma, and W. J. G. Hellstrom, "Update on erectile dysfunction in prostate cancer patients," Current Opinion in Urology, vol. 16, no. 3, pp. 186-195, 2006.

[57] M. J. Resnick, T. Koyama, K. H. Fan et al., "Long-term functional outcomes after treatment for localized prostate cancer," The New England Journal of Medicine, vol. 368, pp. 436-445, 2013.

[58] V. Ficarra, G. Novara, T. E. Ahlering et al., "Systematic review and meta-analysis of studies reporting potency rates after robotassisted radical prostatectomy," European Urology, vol. 62, pp. 418-430, 2012.

[59] Y. Pardo, F. Guedea, F. Aguilo et al., "Quality-of-life impact of primary treatments for localized prostate cancer in patients without hormonal treatment," Journal of Clinical Oncology, vol. 28, pp. 4687-4696, 2010.

[60] M. Fode, D. A. Ohl, D. Ralph et al., "Penile rehabilitation after radical prostatectomy: what the evidence really says," $B J U$ International, vol. 112, no. 7, pp. 998-1008, 2013.

[61] M. Albersen, M. Kendirci, F. van der Aa, W. J. G. Hellstrom, T. F. Lue, and J. L. Spees, "Multipotent stromal cell therapy for cavernous nerve injury-induced erectile dysfunction," The Journal of Sexual Medicine, vol. 9, no. 2, pp. 385-403, 2012.

[62] M. G. Ferrini, H. H. Davila, I. Kovanecz, S. P. Sanchez, N. F. Gonzalez-Cadavid, and J. Rajfer, "Vardenafil prevents fibrosis and loss of corporal smooth muscle that occurs after bilateral cavernosal nerve resection in the rat," Urology, vol. 68, no. 2, pp. 429-435, 2006.

[63] L. T. Klein, M. I. Miller, R. Buttyan et al., "Apoptosis in the rat penis after penile denervation," Journal of Urology, vol. 158, no. 2, pp. 626-630, 1997.

[64] J. J. Lysiak, S. Yang, A. P. Klausner, H. Son, J. B. Tuttle, and W. D. Steers, "Tadalafil increases Akt and extracellular signalregulated kinase 1/2 activation, and prevents apoptotic cell death in the penis following denervation," Journal of Urology, vol. 179, no. 2, pp. 779-785, 2008.

[65] S. Leungwattanakij, T. J. Bivalacqua, M. F. Usta et al., "Cavernous neurotomy causes hypoxia and fibrosis in rat corpus cavernosum," Journal of Andrology, vol. 24, no. 2, pp. 239-245, 2003.

[66] W. Hu, L. Hu, J. Song et al., "Fibrosis of corpus cavernosum in animals following cavernous nerve ablation," Asian Journal of Andrology, vol. 6, no. 2, pp. 111-116, 2004.

[67] F. Iacono, R. Giannella, P. Somma, G. Manno, F. Fusco, and V. Mirone, "Histological alterations in cavernous tissue after radical prostatectomy," Journal of Urology, vol. 173, no. 5, pp. 1673-1676, 2005.
[68] S. Carrier, H. Hricak, S.-S. Lee et al., "Radiation-induced decrease in nitric oxide synthase-containing nerves in the rat penis," Radiology, vol. 195, no. 1, pp. 95-99, 1995.

[69] M. Kimura, H. Yan, Z. Rabbani et al., "Radiation-induced erectile dysfunction using prostate-confined modern radiotherapy in a rat model," The Journal of Sexual Medicine, vol. 8, no. 8, pp. 2215-2226, 2011.

[70] G. Garaffa, L. W. Trost, E. C. Serefoglu et al., "Understanding the course of Peyronie's disease," International Journal of Clinical Practice, vol. 67, pp. 781-788, 2013.

[71] T. J. Walsh, J. M. Hotaling, T. F. Lue et al., "How curved is too curved? The severity of penile deformity may predict sexual disability among men with Peyronie's disease," International Journal of Impotence Research, vol. 25, pp. 109-112, 2013.

[72] J. A. Lopez and J. P. Jarow, "Penile vascular evaluation of men with Peyronie's disease," Journal of Urology, vol. 149, no. 1, pp. 53-55, 1993.

[73] M. Çulha, B. Alici, O. Acar, N. Mutlu, and A. Gökalp, "The relationship between diabetes mellitus, impotence and venoocclusive dysfunction in Peyronie's disease patients," Urologia Internationalis, vol. 60, no. 2, pp. 101-104, 1998.

[74] J. F. Stecker Jr. and C. J. Devine Jr., "Evaluation of erectile dysfunction in patients with Peyronie's disease," Journal of Urology, vol. 132, no. 4, pp. 680-681, 1984.

[75] T. J. Bivalacqua, E. K. Diner, T. E. Novak et al., "A rat model of Peyronie's disease associated with a decrease in erectile activity and an increase in inducible nitric oxide synthase protein expression," Journal of Urology, vol. 163, no. 6, pp. 1992-1998, 2000.

[76] D. Martinez, C. E. Ercole, T. S. Hakky et al., "Peyronie's disease: still a surgical disease," Advances in Urology, vol. 2012, Article ID 206284, 5 pages, 2012.

[77] A. Kadioglu, O. Sanli, T. Akman et al., "Graft materials in Peyronie's disease surgery: a comprehensive review," The Journal of Sexual Medicine, vol. 4, pp. 581-595, 2007.

[78] L. Ma, Y. Yang, S. C. Sikka et al., "Adipose tissue-derived stem cell-seeded small intestinal submucosa for tunica albuginea grafting and reconstruction," Proceedings of the National Academy of Sciences of the United States of America, vol. 109, no. 6, pp. 2090-2095, 2012.

[79] F. Castiglione, P. Hedlund, F. van der Aa et al., "Intratunical injection of human adipose tissue-derived stem cells prevents fibrosis and is associated with improved erectile function in a rat model of Peyronie's disease," European Urology, vol. 63, pp. 551-560, 2013.

[80] J. Y. Bahk, J. H. Jung, H. Han, S. K. Min, and Y. S. Lee, "Treatment of diabetic impotence with umbilical cord blood stem cell intracavernosal transplant: preliminary report of 7 cases," Experimental and Clinical Transplantation, vol. 8, no. 2, pp. 150-160, 2010.

[81] T. J. Bivalacqua, W. Deng, M. Kendirci et al., "Mesenchymal stem cells alone or ex vivo gene modified with endothelial nitric oxide synthase reverse age-associated erectile dysfunction," American Journal of Physiology-Heart and Circulatory Physiology, vol. 292, no. 3, pp. H1278-H1290, 2007.

[82] G. Nolazco, I. Kovanecz, D. Vernet et al., "Effect of musclederived stem cells on the restoration of corpora cavernosa smooth muscle and erectile function in the aged rat," $B J U$ International, vol. 101, no. 9, pp. 1156-1164, 2008.

[83] M. T. Abdel Aziz, S. El-Haggar, T. Mostafa et al., "Effect of mesenchymal stem cell penile transplantation on erectile 
signaling of aged rats," Andrologia, vol. 42, no. 3, pp. 187-192, 2010.

[84] Y. Huang, H. Ning, A. W. Shindel et al., "The effect of intracavernous injection of adipose tissue-derived stem cells on hyperlipidemia-associated erectile dysfunction in a rat model," The Journal of Sexual Medicine, vol. 7, no. 4, pp. 1391-1400, 2010.

[85] M. M. Garcia, T. M. Fandel, G. Lin et al., "Treatment of erectile dysfunction in the obese Type 2 diabetic ZDF rat with adipose tissue-derived stem cells," The Journal of Sexual Medicine, vol. 7, no. 1, pp. 89-98, 2010.

[86] X. Gou, W. He, M. Xiao et al., "Transplantation of endothelial progenitor cells transfected with VEGF165 to restore erectile function in diabetic rats," Asian Journal of Andrology, vol. 13, no. 2, pp. 332-338, 2011.

[87] X. Qiu, H. Lin, Y. Wang et al., "Intracavernous transplantation of bone marrow-derived mesenchymal stem cells restores erectile function of streptozocin-induced diabetic rats," The Journal of Sexual Medicine, vol. 8, no. 2, pp. 427-436, 2011.

[88] X. Qiu, C. Sun, W. Yu et al., "Combined strategy of mesenchymal stem cell injection with vascular endothelial growth factor gene therapy for the treatment of diabetes-associated erectile dysfunction," Journal of Andrology, vol. 33, no. 1, pp. 37-44, 2012.

[89] C. Sun, H. Lin, W. Yu et al., "Neurotrophic effect of bone marrow mesenchymal stem cells for erectile dysfunction in diabetic rats," International Journal of Andrology, vol. 35, pp. 601-607, 2012.

[90] H. Nishimatsu, E. Suzuki, S. Kumano et al., "Adrenomedullin mediates adipose tissue-derived stem cell-induced restoration of erectile function in diabetic rats," The Journal of Sexual Medicine, vol. 9, no. 2, pp. 482-493, 2012.

[91] J. K. Ryu, M. Tumurbaatar, H. R. Jin et al., "Intracavernous delivery of freshly isolated stromal vascular fraction rescues erectile function by enhancing endothelial regeneration in the streptozotocin-induced diabetic mouse," The Journal of Sexual Medicine, vol. 9, pp. 3051-3065, 2012.

[92] Y. He, W. He, G. Qin et al., “Transplantation KCNMA1 modified bone marrow-mesenchymal stem cell therapy for diabetes mellitus-induced erectile dysfunction," Andrologia, 2013.

[93] G. Liu, X. Sun, J. Bian et al., "Correction of diabetic erectile dysfunction with adipose derived stem cells modified with the vascular endothelial growth factor gene in a rodent diabetic model," PLoS ONE, vol. 8, Article ID e72790, 2013.

[94] D. Bochinski, G. T. Lin, L. Nunes et al., "The effect of neural embryonic stem cell therapy in a rat model of cavernosal nerve injury," BJU International, vol. 94, no. 6, pp. 904-909, 2004.

[95] Y. Kim, F. de Miguel, I. Usiene et al., "Injection of skeletal muscle-derived cells into the penis improves erectile function," International Journal of Impotence Research, vol. 18, no. 4, pp. 329-334, 2006.

[96] P. A. Fall, M. Izikki, L. Tu et al., "Apoptosis and effects of intracavernous bone marrow cell injection in a rat model of postprostatectomy erectile dysfunction," European Urology, vol. 56, pp. 716-725, 2009.

[97] M. Albersen, T. M. Fandel, G. Lin et al., "Injections of adipose tissue-derived stem cells and stem cell lysate improve recovery of erectile function in a rat model of cavernous nerve injury," The Journal of Sexual Medicine, vol. 7, no. 10, pp. 3331-3340, 2010.

[98] M. Kendirci, L. Trost, B. Bakondi, M. J. Whitney, W. J. G. Hellstrom, and J. L. Spees, "Transplantation of nonhematopoietic adult bone marrow stem/progenitor cells isolated by p 75 nerve growth factor receptor into the penis rescues erectile function in a rat model of cavernous nerve injury," Journal of Urology, vol. 184, no. 4, pp. 1560-1566, 2010.

[99] G. Lin, M. Albersen, A. M. Harraz et al., "Cavernous nerve repair with allogenic adipose matrix and autologous adiposederived stem cells," Urology, vol. 77, no. 6, pp. 1509.el-1509.e8, 2011.

[100] J. C. Woo, W. J. Bae, S. J. Kim et al., “Transplantation of musclederived stem cells into the corpus avernosum restores erectile function in a rat model of cavernous nerve injury," Korean Journal of Urology, vol. 52, no. 5, pp. 359-363, 2011.

[101] T. M. Fandel, M. Albersen, G. Lin et al., "Recruitment of intracavernously injected adipose-derived stem cells to the major pelvic ganglion improves erectile function in a rat model of cavernous nerve injury," European Urology, vol. 61, no. 1, pp. 201-210, 2012.

[102] S. J. Kim, S. W. Choi, K. J. Hur et al., "Synergistic effect of mesenchymal stem cells infected with recombinant adenovirus expressing human BDNF on erectile function in a rat model of cavernous nerve injury," Korean Journal of Urology, vol. 53, pp. 726-732, 2012.

[103] I. Kovanecz, S. Rivera, G. Nolazco et al., "Separate or combined treatments with daily sildenafil, molsidomine, or musclederived stem cells prevent erectile dysfunction in a rat model of cavernosal nerve damage," The Journal of Sexual Medicine, vol. 9, pp. 2814-2826, 2012.

[104] S. Piao, I. G. Kim, J. Y. Lee et al., "Therapeutic effect of adiposederived stem cells and BDNF-immobilized PLGA membrane in a rat model of cavernous nerve injury," The Journal of Sexual Medicine, vol. 9, pp. 1968-1979, 2012.

[105] X. Qiu, J. Villalta, L. Ferretti et al., "Effects of intravenous injection of adipose-derived stem cells in a rat model of radiation therapy-induced erectile dysfunction," The Journal of Sexual Medicine, vol. 9, pp. 1834-1841, 2012.

[106] X. Qiu, T. M. Fandel, L. Ferretti et al., "Both immediate and delayed intracavernous injection of autologous adipose-derived stromal vascular fraction enhances recovery of erectile function in a rat model of cavernous nerve injury," European Urology, vol. 62, pp. 720-727, 2012.

[107] H. H. Jeong, S. Piao, J. N. Ha et al., "Combined therapeutic effect of udenafil and adipose-derived stem cell (ADSC)/brainderived neurotrophic factor (BDNF)-membrane system in a rat model of cavernous nerve injury," Urology, vol. 81, pp. 1108. e71108. e14, 2013.

[108] I. G. Kim, S. Piao, J. Y. Lee et al., "Effect of an adipose-derived stem cell and nerve growth factor-incorporated hydrogel on recovery of erectile function in a rat model of cavernous nerve injury," Tissue Engineering A, vol. 19, pp. 14-23, 2013.

[109] D. You, M. J. Jang, J. Lee et al., "Periprostatic implantation of human bone marrow-derived mesenchymal stem cells potentiates recovery of erectile function by intracavernosal injection in a rat model of cavernous nerve injury," Urology, vol. 81, pp. 104-110, 2013.

[110] D. You, M. J. Jang, J. Lee et al., "Comparative analysis of periprostatic implantation and intracavernosal injection of human adipose tissue-derived stem cells for erectile function recovery in a rat model of cavernous nerve injury," Prostate, vol. 73, pp. 278-286, 2013.

[111] W. Y. Choi, H. G. Jeon, Y. Chung et al., "Isolation and characterization of novel, highly proliferative human CD34/CD73double-positive testis-derived stem cells for cell therapy," Stem Cells and Development, vol. 22, pp. 2158-2173, 2013. 
[112] C. Ying, M. Yang, X. Zheng et al., "Effects of intracavernous injection of adipose-derived stem cells on cavernous nerve regeneration in a rat model," Cellular and Molecular Neurobiology, vol. 33, pp. 233-240, 2013.

[113] B. F. Koontz, H. Yan, M. Kimura, Z. Vujaskovic, C. Donatucci, and F. Yin, "Feasibility study of an intensity-modulated radiation model for the study of erectile dysfunction," The Journal of Sexual Medicine, vol. 8, no. 2, pp. 411-418, 2011.

[114] G. J. van der Wielen, M. Vermeij, B. W. D. de Jong et al., "Changes in the penile arteries of the rat after fractionated irradiation of the prostate: a pilot study," The Journal of Sexual Medicine, vol. 6, no. 7, pp. 1908-1913, 2009.

[115] L. da Silva Meirelles, P. C. Chagastelles, and N. B. Nardi, "Mesenchymal stem cells reside in virtually all post-natal organs and tissues," Journal of Cell Science, vol. 119, no. 11, pp. 22042213, 2006.

[116] M. Crisan, S. Yap, L. Casteilla et al., "A perivascular origin for mesenchymal stem cells in multiple human organs," Cell Stem Cell, vol. 3, no. 3, pp. 301-313, 2008.

[117] G. Lin, M. Garcia, H. Ning et al., "Defining stem and progenitor cells within adipose tissue," Stem Cells and Development, vol. 17, no. 6, pp. 1053-1063, 2008.

[118] J. Braun, A. Kurtz, N. Barutcu et al., "Concerted regulation of CD34 and CD105 accompanies mesenchymal stromal cell derivation from human adventitial stromal cell," Stem Cells and Development, vol. 22, pp. 815-827, 2013.

[119] M. Corselli, C. W. Chen, B. Sun et al., "The tunica adventitia of human arteries and veins as a source of mesenchymal stem cells," Stem Cells and Development, vol. 21, pp. 1299-1308, 2012.

[120] G. Lin, Z. Xin, H. Zhang et al., "Identification of active and quiescent adipose vascular stromal cells," Cytotherapy, vol. 14, no. 2, pp. 240-246, 2012.

[121] M. Maumus, J.-A. Peyrafitte, R. D’Angelo et al., "Native human adipose stromal cells: localization, morphology and phenotype," International Journal of Obesity, vol. 35, no. 9, pp. 1141-1153, 2011.

[122] L. Zimmerlin, V. S. Donnenberg, M. E. Pfeifer et al., "Stromal vascular progenitors in adult human adipose tissue," Cytometry A, vol. 77, no. 1, pp. 22-30, 2010.

[123] C. S. Lin and T. F. Lue, "Defining vascular stem cells," Stem Cells and Development, vol. 22, pp. 1018-1026, 2013.

[124] M. Dominici, K. Le Blanc, I. Mueller et al., "Minimal criteria for defining multipotent mesenchymal stromal cells. The International Society for Cellular Therapy position statement," Cytotherapy, vol. 8, no. 4, pp. 315-317, 2006.

[125] C. S. Lin and T. F. Lue, "Adipose-derived stem cells: therapy through paracrine actions," in Stem Cells and Cancer Stem Cells, M. A. Hayat, Ed., vol. 4, pp. 203-216, Springer, New York, NY, USA, 2012.

[126] C. S. Lin, Z. C. Xin, J. Dai et al., "Commonly used mesenchymal stem cell markers and tracking labels: limitations and challenges," Histology and Histopathology, vol. 28, pp. 1109-1116, 2013.

[127] C. S. Lin, H. Ning, G. Lin et al., "Is CD34 truly a negative marker for mesenchymal stromal cells?" Cytotherapy, vol. 14, pp. 11591163, 2012.

[128] P. J. Simmons and B. Torok-Storb, "Identification of stromal cell precursors in human bone marrow by a novel monoclonal antibody, STRO-1," Blood, vol. 78, no. 1, pp. 55-62, 1991.

[129] P. J. Simmons and B. Torok-Storb, "CD34 expression by stromal precursors in normal human adult bone marrow," Blood, vol. 78, no. 11, pp. 2848-2853, 1991.
[130] C. M. Kolf, E. Cho, and R. S. Tuan, "Mesenchymal stromal cells. Biology of adult mesenchymal stem cells: regulation of niche, self-renewal and differentiation," Arthritis Research and Therapy, vol. 9, no. 1, pp. 204-213, 2007.

[131] G. Lin, G. Liu, L. Banie et al., "Tissue distribution of mesenchymal stem cell marker stro-1," Stem Cells and Development, vol. 20, no. 10, pp. 1747-1752, 2011.

[132] A. I. Caplan and D. Correa, "The MSC: an injury drugstore," Cell Stem Cell, vol. 9, no. 1, pp. 11-15, 2011.

[133] D. J. Prockop and J. Y. Oh, "Medical therapies with adult stem/progenitor cells (MSCs): a backward journey from dramatic results in vivo to the cellular and molecular explanations," Journal of Cellular Biochemistry, vol. 113, no. 5, pp. 1460-1469, 2012.

[134] M. B. Murphy, K. Moncivais, and A. I. Caplan, "Mesenchymal stem cells: environmentally responsive therapeutics for regenerative medicine," Experimental \& Molecular Medicine, vol. 45, article e54, 2013.

[135] D. Brenin, J. Look, M. Bader, N. Hübner, G. Levan, and P. Iannaccone, "Rat embryonic stem cells: a progress report," Transplantation Proceedings, vol. 29, no. 3, pp. 1761-1765, 1997.

[136] M. Kawamata and T. Ochiya, "Establishment of embryonic stem cells from rat blastocysts," Methods in Molecular Biology, vol. 597, pp. 169-177, 2010.

[137] M. Schulze, H. Ungefroren, M. Bader, and F. Fändrich, “Derivation, maintenance, and characterization of rat embryonic stem cells in vitro," Methods in Molecular Biology, vol. 329, pp. 45-58, 2006.

[138] H. Ning, G. Lin, T. F. Lue, and C. Lin, "Neuron-like differentiation of adipose tissue-derived stromal cells and vascular smooth muscle cells," Differentiation, vol. 74, no. 9-10, pp. 510-518, 2006.

[139] A. B. Mathiasen, E. Jorgensen, A. A. Qayyum et al., "Rationale and design of the first randomized, double-blind, placebocontrolled trial of intramyocardial injection of autologous bone-marrow derived Mesenchymal Stromal Cells in chronic ischemic Heart Failure (MSC-HF Trial)," American Heart Journal, vol. 164, pp. 285-291, 2012.

[140] T. Asahara and J. M. Isner, "Endothelial progenitor cells for vascular regeneration," Journal of Hematotherapy and Stem Cell Research, vol. 11, no. 2, pp. 171-178, 2002.

[141] C. Foresta, N. Caretta, A. Lana, A. Cabrelle, G. Palù, and A. Ferlin, "Circulating endothelial progenitor cells in subjects with erectile dysfunction," International Journal of Impotence Research, vol. 17, no. 3, pp. 288-290, 2005.

[142] C. Foresta, N. Caretta, A. Lana et al., "Relationship between vascular damage degrees and endothelial progenitor cells in patients with erectile dysfunction: effect of vardenafil administration and PDE5 expression in the bone marrow," European Urology, vol. 51, no. 5, pp. 1411-1419, 2007.

[143] C. Foresta, A. Ferlin, L. de Toni et al., "Circulating endothelial progenitor cells and endothelial function after chronic Tadalafil treatment in subjects with erectile dysfunction," International Journal of Impotence Research, vol. 18, no. 5, pp. 484-488, 2006.

[144] M. Baumhäkel, N. Werner, M. Böhm, and G. Nickenig, "Circulating endothelial progenitor cells correlate with erectile function in patients with coronary heart disease," European Heart Journal, vol. 27, no. 18, pp. 2184-2188, 2006.

[145] K. Esposito, M. Ciotola, M. I. Maiorino et al., "Circulating $\mathrm{CD} 34+\mathrm{KDR}+$ endothelial progenitor cells correlate with erectile function and endothelial function in overweight men," The Journal of Sexual Medicine, vol. 6, no. 1, pp. 107-114, 2009. 
[146] T. E. Ichim, Z. Zhong, N. A. Mikirova et al., "Circulating endothelial progenitor cells and erectile dysfunction: possibility of nutritional intervention?" Panminerva Medica, vol. 52, no. 2, pp. 75-80, 2010.

[147] S. la Vignera, R. Condorelli, E. Vicari, R. D’Agata, and A. E. Calogero, "Circulating endothelial progenitor cells and endothelial microparticles in patients with arterial erectile dysfunction and metabolic syndrome," Journal of Andrology, vol. 33, no. 2, pp. 202-209, 2012.

[148] S. la Vignera, R. Condorelli, E. Vicari, R. D’Agata, and A. Calogero, "Original immunophenotype of blood endothelial progenitor cells and microparticles in patients with isolated arterial erectile dysfunction and late onset hypogonadism: effects of androgen replacement therapy," Aging Male, vol. 14, no. 3, pp. 183-189, 2011.

[149] S. la Vignera, R. A. Condorelli, E. Vicari, R. D’Agata, and A. E. Calogero, "New immunophenotype of blood endothelial progenitor cells and endothelial microparticles in patients with arterial erectile dysfunction and late-onset hypogonadism," Journal of Andrology, vol. 32, no. 5, pp. 509-517, 2011.

[150] M. C. Yoder and D. A. Ingram, "Endothelial progenitor cell: ongoing controversy for defining these cells and their role in neoangiogenesis in the murine system," Current Opinion in Hematology, vol. 16, no. 4, pp. 269-273, 2009.

[151] A. Mohammad and A. Shuaib, "Endothelial progenitor cells and vascular disease: are they for real?” Neurology, vol. 75, no. 23, pp. 2050-2051, 2010.

[152] M. Prokopi, G. Pula, U. Mayr et al., "Proteomic analysis reveals presence of platelet microparticles in endothelial progenitor cell cultures," Blood, vol. 114, no. 3, pp. 723-732, 2009.

[153] M. C. Yoder, "Is endothelium the origin of endothelial progenitor cells?" Arteriosclerosis, Thrombosis, and Vascular Biology, vol. 30, pp. 1094-1103, 2010.

[154] M. R. Richardson and M. C. Yoder, "Endothelial progenitor cells: quo vadis?" Journal of Molecular and Cellular Cardiology, vol. 50, no. 2, pp. 266-272, 2011.

[155] M. C. Yoder, "Endothelial progenitor cell: a blood cell by many other names may serve similar functions," Journal of Molecular Medicine, vol. 91, pp. 285-295, 2013.

[156] F. Timmermans, J. Plum, M. C. Yöder, D. A. Ingram, B. Vandekerckhove, and J. Case, "Endothelial progenitor cells: identity defined?" Journal of Cellular and Molecular Medicine, vol. 13, no. 1, pp. 87-102, 2009.

[157] J. Z. Shi, H. Zhang, M. Hou et al., "Is it possible to obtain "true endothelial progenitor cells" by in vitro culture of bone marrow mononuclear cells?" Stem Cells and Development, vol. 16, no. 4, pp. 683-690, 2007.

[158] J. L. Goldberg, M. J. Laughlin, and V. J. Pompili, "Umbilical cord blood stem cells: implications for cardiovascular regenerative medicine," Journal of Molecular and Cellular Cardiology, vol. 42, no. 5, pp. 912-920, 2007.

[159] J. H. Park, I. Hwang, S. H. Hwang et al., "Human umbilical cord blood-derived mesenchymal stem cells prevent diabetic renal injury through paracrine action," Diabetes Research and Clinical Practice, vol. 98, pp. 465-473, 2012.

[160] T. Yokoyama, R. Pruchnic, J. Y. Lee et al., "Autologous primary muscle-derived cells transfer into the lower urinary tract," Tissue Engineering, vol. 7, no. 4, pp. 395-404, 2001.

[161] T. Yokoyama, N. Yoshimura, R. Dhir et al., "Persistence and survival of autologous muscle derived cells versus bovine collagen as potential treatment of stress urinary incontinence," Journal of Urology, vol. 165, no. 1, pp. 271-276, 2001.
[162] A. Furuta, L. K. Carr, N. Yoshimura et al., "Advances in the understanding of sress urinary incontinence and the promise of stem-cell therapy," Reviews in Urology, vol. 9, pp. 106-112, 2007.

[163] P. A. Zuk, M. Zhu, H. Mizuno et al., "Multilineage cells from human adipose tissue: implications for cell-based therapies," Tissue Engineering, vol. 7, no. 2, pp. 211-228, 2001.

[164] Y. C. Halvorsen, W. O. Wilkison, and J. M. Gimble, "Adiposederived stromal cells - their utility and petential in bone formation," International Journal of Obesity, vol. 24, supplement 4, pp. S41-S44, 2000.

[165] S. Gronthos, D. M. Franklin, H. A. Leddy et al., "Surface protein characterization of human adipose tissue-derived stromal cells," Journal of Cellular Physiology, vol. 189, pp. 54-63, 2001.

[166] Y. C. Halvorsen, A. Bond, A. Sen et al., "Thiazolidinediones and glucocorticoids synergistically induce differentiation of human adipose tissue stromal cells: biochemical, cellular, and molecular analysis," Metabolism, vol. 50, no. 4, pp. 407-413, 2001.

[167] Y.-D. C. Halvorsen, D. Franklin, A. L. Bond et al., "Extracellular matrix mineralization and osteoblast gene expression by human adipose tissue-derived stromal cells," Tissue Engineering, vol. 7, no. 6, pp. 729-741, 2001.

[168] A. Sen, Y. R. Lea-Currie, D. Sujkowska et al., "Adipogenic potential of human adipose derived stromal cells from multiple donors is heterogeneous," Journal of Cellular Biochemistry, vol. 81, pp. 312-319, 2001.

[169] P. Wu, K. Sato, S. Yukawa, Y. Hikasa, and K. Kagota, “Differentiation of stromal-vascular cells isolated from canine adipose tissues in primary culture," Journal of Veterinary Medical Science, vol. 63, no. 1, pp. 17-23, 2001.

[170] P. Pettersson, M. Cigolini, and L. Sjostrom, "Cells in human adipose tissue developing into adipocytes," Acta Medica Scandinavica, vol. 215, no. 5, pp. 447-451, 1984.

[171] B. M. Strem, K. C. Hicok, M. Zhu et al., "Multipotential differentiation of adipose tissue-derived stem cells," Keio Journal of Medicine, vol. 54, no. 3, pp. 132-141, 2005.

[172] T. K. Kim and J. H. Eberwine, "Mammalian cell transfection: the present and the future," Analytical and Bioanalytical Chemistry, vol. 397, no. 8, pp. 3173-3178, 2010.

[173] C. S. Lin, G. Lin, and T. F. Lue, "Allogeneic and xenogeneic transplantation of adipose-derived stem cells in immunocompetent recipients without immunosuppressants," Stem Cells and Development, vol. 21, pp. 2770-2778, 2012.

[174] J. M. Hare, J. E. Fishman, G. Gerstenblith et al., "Comparison of allogeneic vs autologous bone marrow-derived mesenchymal stem cells delivered by transendocardial injection in patients with ischemic cardiomyopathy: the POSEIDON randomized trial," Journal of the American Medical Association, vol. 308, pp. 2369-2379, 2012.

[175] G. Lin, X. Qiu, T. Fandel et al., "Tracking intracavernously injected adipose-derived stem cells to bone marrow," International Journal of Impotence Research, vol. 23, no. 6, pp. 268-275, 2011.

[176] H. Zhang, H. Ning, L. Banie et al., "Adipose tissue-derived stem cells secrete CXCL5 cytokine with chemoattractant and angiogenic properties," Biochemical and Biophysical Research Communications, vol. 402, no. 3, pp. 560-564, 2010.

[177] H. Zhang, R. Yang, Z. Wang, G. Lin, T. F. Lue, and C. Lin, "Adipose tissue-derived stem cells secrete CXCL5 cytokine with neurotrophic effects on cavernous nerve regeneration," The Journal of Sexual Medicine, vol. 8, no. 2, pp. 437-446, 2011. 
[178] E. D. Kim, R. Nath, K. M. Slawin, D. Kadmon, B. J. Miles, and P. T. Scardino, "Bilateral nerve grafting during radical retropubic prostatectomy: extended follow-up," Urology, vol. 58, no. 6, pp. 983-987, 2001.

[179] B. A. Nelson, S. S. Chang, M. S. Cookson, and J. A. Smith Jr., "Morbidity and efficacy of genitofemoral nerve grafts with radical retropubic prostatectomy," Urology, vol. 67, no. 4, pp. 789-792, 2006.

[180] G. Lin, G. Wang, L. Banie et al., "Treatment of stress urinary incontinence with adipose tissue-derived stem cells," Cytotherapy, vol. 12, no. 1, pp. 88-95, 2010.

[181] Y. Huang, A. W. Shindel, H. Ning et al., "Adipose derived stem cells ameliorate hyperlipidemia associated detrusor overactivity in a rat model," Journal of Urology, vol. 183, no. 3, pp. 1232-1240, 2010.

[182] H. Ning, G. Liu, G. Lin, R. Yang, T. F. Lue, and C. Lin, "Fibroblast growth factor 2 promotes endothelial differentiation of adipose tissue-derived stem cell," The Journal of Sexual Medicine, vol. 6, no. 4, pp. 967-979, 2009. 


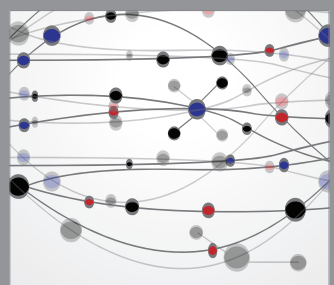

The Scientific World Journal
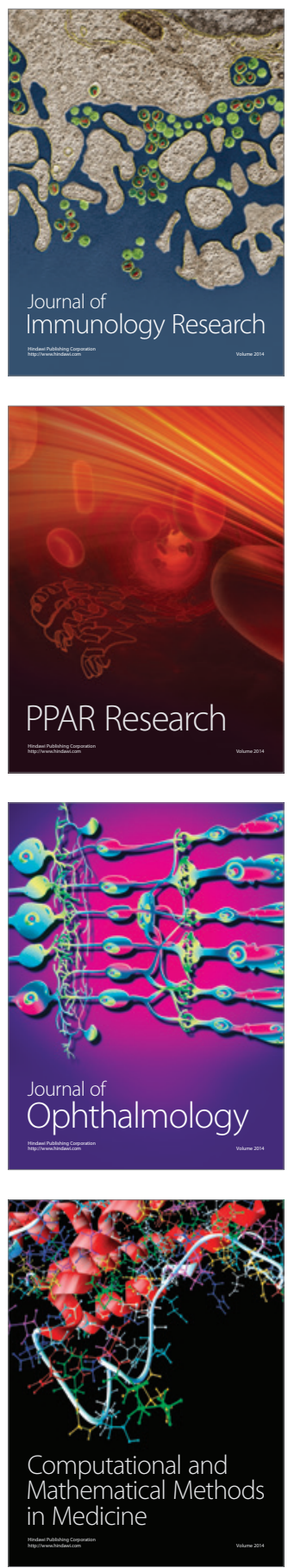

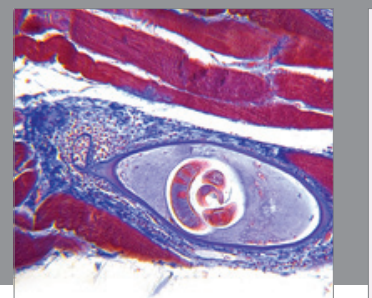

Gastroenterology

Research and Practice
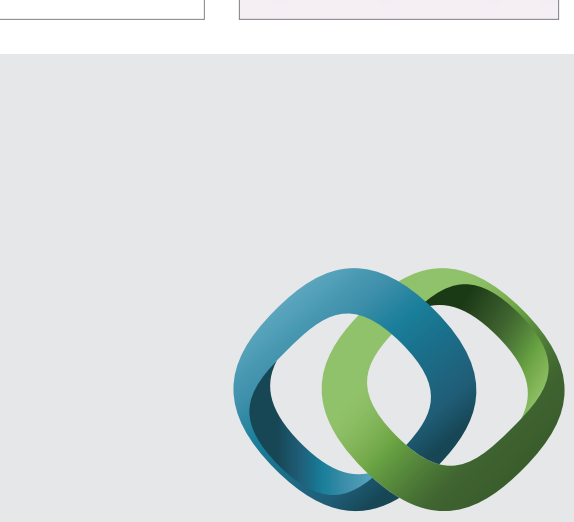

\section{Hindawi}

Submit your manuscripts at

http://www.hindawi.com
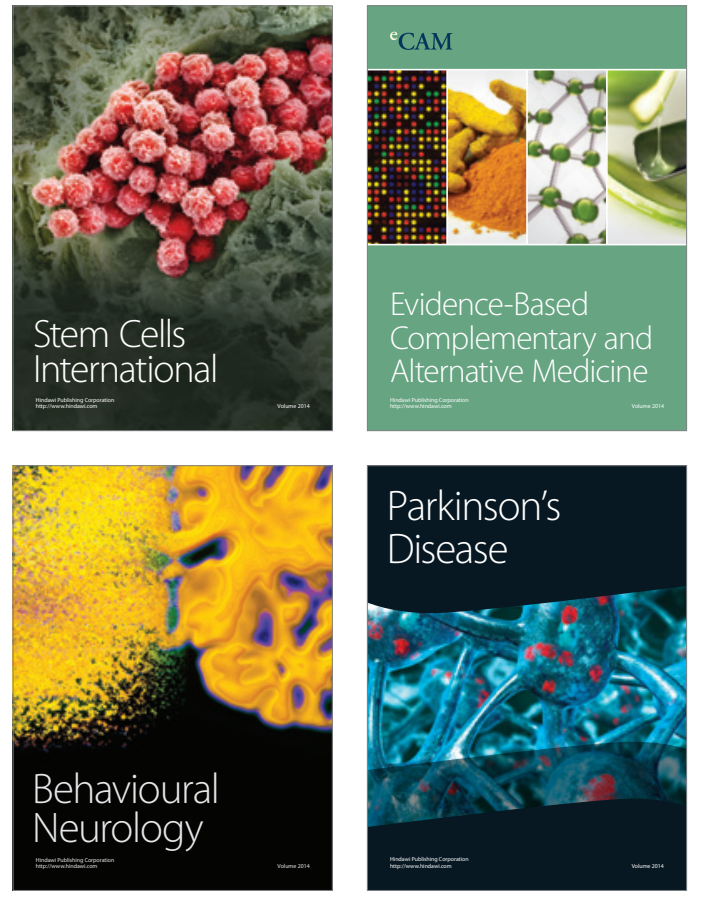
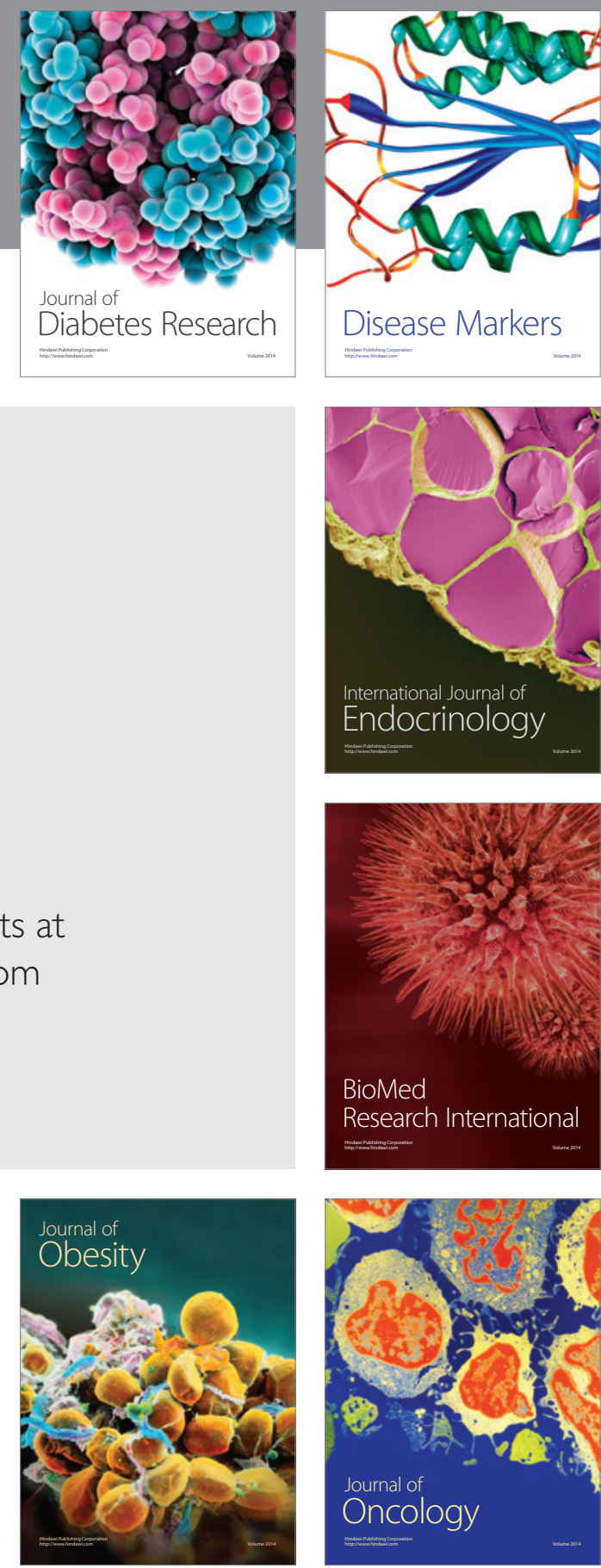

Disease Markers
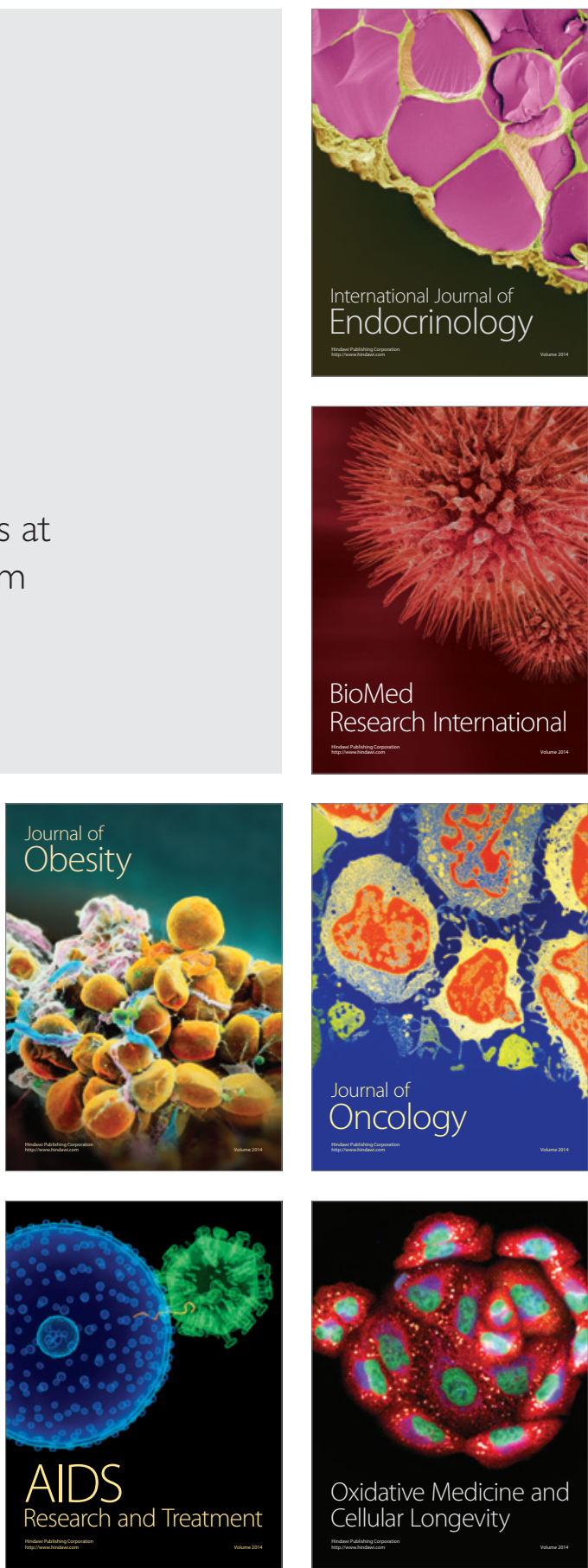